\title{
Paulo de Tarso e os componentes gregos do seu pensamento
}

Romano Penna

Na história da pesquisa sobre as relações entre Paulo e o helenismo ficou célebre aquilo que escreveu ironicamente Albert Schweitzer em 1930 a propósito da inutilidade de se recorrer ao helenismo para explicar o pensamento do Apóstolo. Isso, de fato, compreensível somente em base à escatologia judaica: "Aqueles que se esforçam por explicar o pensamento paulino com base no helenismo são comparáveis a quem quer transportar de longe água em regadores furados para irrigar um jardim plantado às margens de um riacho"! Fora da metáfora, ainda que seja indiscutível a possibilidade de Paulo juntamente com a língua grega ter assumido idéias helênicas, todavia "a maior parte daquilo que até agora foi adotado da literatura grega para explicar o mundo conceitual de Paulo, não lhe lançou as luzes que se esperava"1. Schweitzer escrevia estas palavras especificamente a propósito da mística paulina, que segundo ele encontraria sua sustentabilidade somente no conceito de uma escatologia já realizada mediante a participação do cristão em Cristo ressuscitado. As suas palavras são ainda mais singulares em quanto ele provinha de uma estação, aquela da "religionsgeschichtliche Schule", que, repetidamente, havia buscado explicar o melhor das origens cristãs e, especialmente, do paulinismo recorrendo, sobretudo, à helinidade e ao seu

\footnotetext{
${ }^{1}$ SCHWEITZER, A., Die Mystik des Apostels Paulus, Mohr, Tübingen ${ }^{2} 1954$ (= 1930), $140 \mathrm{e}$ 138.
} 
enorme patrimônio cultural e religioso, atracando, entretanto, em desvios sincretistas. $^{2}$

Mas daquele tempo até hoje a pesquisa fez grandes progressos, seja a nível de um maior conhecimento das fontes, seja da aplicação sobre elas de uma metodologia adequada, e como conseqüência, uma maior cautela em tirar conclusões acerca disso. Um reconhecido estudioso das origens cristãs, como o dinamarquês Prof. Engberg-Pedersen da Universidade de Copenhagen, chega a escrever que "Paulo não era nem especificamente judeu e nem especificamente grego"3, querendo dizer com isso que o Apóstolo, mesmo devendo se colocar sem dúvida dentro do judaísmo, era na verdade, um judeu helenista de Tarso e vivia em um ambiente em que o Judaísmo havia sofrido de diversos modos um processo de helenização. ${ }^{4}$ Admitir uma conclusão de tal gênero é apenas o mínimo que se pode afirmar. De fato, varias publicações se interessaram a uma específica comparação entre Paulo e o mundo greco-romano, produzindo interessantes documentos seja a nível geral $^{5}$ como particular ${ }^{6}$. Uma publicação recentíssima enumera, a despeito, 236 textos paulinos que implicariam em igual número de paralelismos com

${ }^{2}$ Em geral, cf. W.G. Kümmel, Das Neue Testament. Geschichte der Forschung seiner Probleme, K. Alber, Freiburg-München 1958, ${ }^{2}$ 1970, 310-357 («Die religionsgeschichtliche Schule»). Ainda, entre as produções daquela época, deve-se acrescentar, no âmbito alemão, G. Anrich, Das antike Mysterienwesen in seinem Einfluss auf das Christentum, Vandenhoeck, Göttingen 1894; e, no âmbito italiano, V. Macchioro, Orfismo e paolinismo, Ed. Cultura Moderna, Montevarchi 1922.

${ }^{3}$ T. Engberg-Pedersen, ed., Paul in His Hellenistic Context, T\&T Clark, Edinburgh 1994, XIX.

4 Veja o clássico estudo de M. Hengel, Judentum und Hellenismus. Studien zu ihrer Begegnung unter besonderer Berücksichtigung Palästinas bis zur Mitte des 2.Jh v.Chr, WUNT 10, Mohr, Tübingen 1969. Cf. anche D.E. Aune, «Religioni greco-romane», in Dizionario di Paolo e delle sue lettere, a cura di G.F. Hawthorne-R.P. Martin-D.G. Reid, a cura, San Paolo, Cinisello Balsamo 1999, 1293-1310 esp. 1306.

${ }^{5}$ Cf. N. Hugedé, Saint Paul et la culture grecque, Genève-Paris 1966; E.M. Yamauchi, «Ellenismo», in Dizionario di Paolo e delle sue lettere, 528-536; T. Engeberg-Pedersen, ed., Paul Beyond the Judaism/Hellenism Divide, Westminster, Louisville 2001; J.P. Sampley, Paul in the Greco-Roman World. A Handbook, Trinity Press, Harrisburg-London-New York 2003.

${ }^{6}$ Cf., por exemplo, G. Wagner, Pauline Baptism and The Pagan Mysteries. The Problem of the Pauline Doctrine of Bapism in Romans VI.1-11, in the Light of its Religio-Historical "Parallels", Oliver \& Boyd, Edinburgh-London 1967; P. Rossano, «Morale ellenistica e morale paolina», in Aa.Vv., Fondamenti biblici della teologia morale. Atti della XXII settimana biblica, Paideia, Brescia 1973, 173-185; A.J.M. Wedderburn, «The Soteriology of the Mysteries and Pauline Baptismal Theology», NT 29 (1987) 53-72; F.G. Downing, Cynics, Paul and the Pauline Churches, Routledge, London-New York 1988; C.E. Glad, Paul and Philodemus. Adaptability in Epicurean and Early Christian Psychagogy, NT Suppl. 81, Brill, Leiden-New York 1995; T. Engberg-Pedersen, Paul and the Stoics, T\&T Clark, Edinburgh 2000. 
fontes pagãs diversas, mesmo que às vezes as coincidências sejam um pouco tangenciais. ${ }^{7}$

\section{Pontuação metodológicas}

Nas páginas que seguem são tomadas em consideração somente as cartas de Paulo (não o livro dos Atos dos Apóstolos), e apenas as cartas das quais a autenticidade não é colocada em discussão. A respeito destas cartas, além da questão da língua grega empregada por Paulo, não examinarei dois âmbitos específicos do helenismo contemporâneo às origens cristãs, mesmo que sejam objeto de comparação: um diz respeito ao confronto das igrejas paulinas com as associações religiosas ou com as escolas filosóficas do tempo ${ }^{8}$; o outro refere-se ao eventual admissão e constatação de elementos próprios da retórica clássica nas cartas do Apóstolo ${ }^{9}$ (com eventual particular referência ao gênero da diatribe). ${ }^{10}$ Dois setores concernem respectivamente ao aspecto sócio-religioso das comunidades paulinas e a dimensão puramente formal de sua composição epistolar. Ambas as matérias são desde muito tempo objeto de estudo e provocaram uma ampla bibliografia. ${ }^{11}$

\footnotetext{
${ }^{7}$ Cf. C.A. Evans, «Paul and the Pagans», in S.E. Porter, ed., Paul: Jew, Greek, and Roman, Pauline Studies 5, Brill, Leiden-Boston 2008, 117-139 (além disso, vem calculados também 22 textos nos Atos).

${ }^{8}$ Cf. em especial J.S. Kloppenborg \& S.G. Wilson, edd., Voluntary Associations in the Graeco-Romans World, London 1996; U. Egelhaaf-Gaiser \& A. Schäfer, edd., Religiöse Vereine in der römischen Antike, STAC 13, Mohr, Tübingen 2002; P.A. Harland, Associations, Synagogues, and Congregations: Claiming a Place in Ancient Mediterranean Society, Fortress, Minneapolis 2003; R. Penna, "Chiese domestiche e culti privati pagani alle origini del cristianesimo. Un confronto», em Id., Vangelo e inculturazione. Studi sul rapporto tra rivelazione e cultura nel Nuovo Testamento, SBA 6, San Paolo, Cinisello Balsamo 2001, 746770; Id., «La casa come ambito cultuale nelle chiese paoline», imminente in RSB 2009.

${ }^{9}$ Cf. De modo especial G.A. Kennedy, Classical Rhetoric and Its Christian and Secular Tradition from Ancient to Modern Times, Chapel Hill NC 1980; Id., New Testament Interpretation through Rhetorical Criticism, Chapel Hill/London 1984; S.E. Porter \& T.H. Olbricht, edd., Rhetoric and the New Testament: Essays from the 1992 Heidelberg Conference, JSNT Suppl. 90, Sheffield 1993; R.D. Anderson, Ancient Rhetorical Theory and Paul, BET 18, Kampen 1996; J.-N. Aletti, «Paul et la rhétorique. Etat de la question et propositions», in J. Schlosser, dir., Paul de Tarse. Congrès de l'ACFEB (Strasbourg, 1995), LD 165, Paris 1996, 27-50; S.E. Poter \& D.L. Stamps, edd., The Rhetorical Interpretation of Scripture. Essays from the 1996 Malibu Conference, JSNT Suppl. 180, Sheffield 1999; R. Penna, «La questione della dispositio rhetorica nella lettera di Paolo ai Romani: confronto con la lettera 7 di Platone e la lettera 95 di Seneca», Bibl 84 (2003) 61-88.

${ }^{10}$ Cf. S.K. Stowers, The Diatribe and Paul's Letter to the Romans, Scholars, Chico CA 1981; Ch. Song, Reading Romans as a Diatribe, SBL 59, Lang, New York-Bern 2004.

${ }^{11}$ Um outro aspecto deixarei de lado que é o que diz respeito à titulação própria dos responsáveis das comunidades cristãs (proistámenos, episcopos, diákonos, prostátēs) na medida em que esses termos tem um correspondente voltado para a vertente grega (cf. A.D. Clarke, $A$
} 
Procederei não pelo exame de específicos textos paulinos ${ }^{12}$, mas por comparação de temas ou conceitos próprios do Apóstolo na medida em que esses apresentam evidentes paralelismos com análogos temas e conceitos próprios do helenismo. O âmbito da referência de comparação é representado naturalmente pelo helinismo, mas sem ignorar que o mundo cultural da primeira idade imperial inclui necessariamente a latinidade pelo fato de ela ser dependente da cultura grega ${ }^{13}$, sobretudo se consideramos o quanto um filosofo hebreu como Fílon de Alexandria escreve a propósito de Otaviano Augusto, que teria "acrescentado à Hélade de muitas outras Hélades"14.

Deixo, no entanto, de fora uma série de vocábulos importantes, com os relativos conceitos, que, não tendo um termo correspondente em hebraico, são explicados somente em base ao léxico grego ${ }^{15}$. Assim acontece com egkráteia (Gl 5,23; com o verbo egkrateúomai em 1Cor 7,9; 9,25), euschēmosýnē (1Cor 12,23: e derivados: Rm 13,13; 1Cor 7,35; 12,24; 14,40; 1Ts 4,12), paidagōgós (1Cor 4,15; Gl 3,24.25), parousía (empregado por Paulo tanto no sentido histórico-biográfico: 1 Cor 16,$17 ; 2$ Cor $7,6.7 ; 10,10 ; \mathrm{Fl} 1,26 ; 2,12$; quanto em sentido cristológico-escatologico: 1 Cor 15,$23 ; 1 \mathrm{Ts} 2,19 ; 3,13 ; 4,15 ; 5,23)$, politeuma $(\mathrm{Fl}$ 3,20; com o verbo politeúesthai em Fl 1,27), prokopē (Fl 1,12.25), syneídēsis (Rm 2,15; 9,1; 13,5; 1 Cor 8,7.10.12; 10,25.27.28.29; 2Cor 1,12; 4,2; 5,11; cf. o verbo em 1Cor 4,4), hyiothesía ( $\operatorname{Rm~8,15.23;~9,4;~Gal~4,5).A~esta~série~são~a-~}$ crescidos todos os vocábulos provenientes do âmbito esportivo: agōn (F1 1,30; 1Ts 2,2; com o verbo agōnízomai em 1Cor 9,25), brabeîon (1Cor 9,24; Fl 3,14), pykteúō (1Cor 9,26), stádion (1Cor 9,24), stéfanos (1Cor 1Cor 9,25; Fl 4,1; 1Ts 2,19), synathléō (F1 1,27; 4,3), tréchō (Rm 9,16; 1Cor 9,24.26; Gal 2,2; 5,7; F1 2,16). Todos estes vocábulos, se não são ausentes da versão da LXX (brabeîon, paidagōgós e hyiothesía não aparecem jamais) ${ }^{16}$, são raramente atestados e não com o valor semântico que lhes é atribuído por Paulo ${ }^{17}$.

Puline Theology of Chiucrh Leaders, LNTS 362, T\&T Clark, London-New York 2008, 42 78).

${ }^{12}$ Assim procede, ao inverso, a monografia de T. Engberg-Pedersen, Paul and the Stoics, T\&T Clark, Edinburgh 2000.

${ }^{13}$ Veja também R. Wallace \& W. Williams, The Three Worlds of Paul of Tarsus, Routledge, London 1994 (os autores são dois clássicos).

${ }^{14}$ Filone Al., Leg. ad C. 146-147.

${ }^{15}$ Para alguns desses, cf. C.A. Evans, «Paul and the Pagans», 126-136.

${ }^{16}$ Veja porém agōn e o verbo brabeúesthai em Sb 10,12. O lexema stádion (Dn 4,9; 13,37; $2 \mathrm{Mac} 11,5 ; 12,9.10 .16 .17 .29)$ tem o significado de medida de distância, mas não de lugar de jogos.

${ }^{17}$ Quanto a parousía, aparece em Ne 2,6; Gdt 10,18; 2Mac 8,12; 15,21, não tem nunca a semântica escatológica própria de Paolo. Políteuma é encontrada somente em 2Mac 12,7. Quanto a syneidésis, a única ocorrência afinada com Paolo é Sb 17,11; Contudo em Qoh 
O meu interesse, entretanto, se limita a tomar especialmente alguns elementos de conteúdo do verdadeiro e próprio pensamento paulino, em quanto oferecem pintas de pesquisa, essencialmente em relação a dois setores fundamentais do helenismo: a filosofia e a religião.

Certamente pode ser que, como sustenta enfaticamente Hengel, todos os elementos da doutrina paulina, em quanto não tenham sido modelados pelo próprio Paulo e aparentemente tenham origem grega ou 'oriental', são, no entanto, mediados pelo judaísmo e suas múltiplas nuanças (inclusive aquela do judaísmo helênico $)^{18}$. Mas em todo caso trata-se de reencontrar, para além de toda mediação, aqueles exatos componentes que na sua origem encontravam-se de fato no âmbito grego. Um exemplo típico neste sentido é o tema do conhecimento natural de Deus: documentado em $\mathrm{Rm}$ 1,19-20, este certamente remete a uma baliza da filosofia grega (que vai ao menos de Platão a Dion de Prusa), mas que chega até Paulo mediado por uma reflexão própria do judaísmo helênico que se pode encontrar em Sb 13 (e também em Filón de Alexandria). ${ }^{19}$

Não obstante o fato de Paulo equiparar polemicamente a sophi$a$ ssabedoria com a mōría/oucura (cf. 1Cor 1,22-24), isto acontece somente a propósito do anúncio da cruz de Cristo e do seu significado ${ }^{20}$. Em muitos casos, ao contrário, a proximidade, e até mesmo a divida em relação à helenidade é, de toda forma, um dado real que é constatado e honrado por si mesmo.

\section{O condicionamento cultural de Tarso}

Logo de início, por seu nascimento em Tarso da Cilícia, e assim a diferença com Jesus ligado, ao contrário, ao pequeno vilarejo galilaico de Nazaré $^{21}$, Paulo devia ser dotado de uma estrutura mental tendencialmente aper-

10,20 (tradução do hebraico $m a d \bar{a}^{c}$ ) o sentido é aquele de «pensamento» (com o obejto, o rei), enquanto em Sir 42,18 se trata somente de uma variante em S. Paulo, frequentes são stéfanos e tréchō, mas não em contextos esportivos.

${ }^{18}$ Cf. M. Hengel \& A.M Schwemer, Paul between Damascus and Antioch. The Unknown Years, SCM Press, London 1997, 282-283.

${ }^{19}$ Cf. R. Penna, Lettera ai Romani, I, EDB, Bologna 2004, 175-180.

${ }^{20}$ De resto, para esclarecer, a confissão de Deus como único verdadeiro sapiente (cf. 1Cor 1,19-20; Rm 16,27) é direcionável, nada menos que a Sócrates, segundo o qual, confrontada com a sabedoria divina, "a sabedoria humana vale poouco ou nada" (Platone, Apol. 23a)! Sobre a tradição socrática em Paulo, cf. H.D. Betz, Der Apostel Paulus und die sokratische Tradition, Mohr, Tübingen 1972, no entanto, o estudo concerne essencialmente ao uso da ironia.

${ }^{21}$ Sobre o influxo da cultura helenística na Galiléia nos tempos de Jesus, cf. R.A. Horsley, Galilea. Storia, politica, popolazione, Paideia, Brescia 2006 (orig. ingl. 1995), 313-333; M.A. Chancey, Greco-Roman Culture and the Galilee of Jesus, SNTS MS 134, University Press, Cambridge 2005. 
ta ao patrimônio ideal típico do helenismo. A importância cultural de Tarso, de fato, gozava de uma fama notável, como atesta o geógrafo Estrabão, que de Paulo foi em parte contemporâneo (ce. 63 a.C. - 21 d.C.): "Tanta paixão têm os homens (de Tarso) pela filosofia e por todas as outras formações enciclopédicas, a ponto de superar Atenas, Alexandria e qualquer outro lugar em que surgem escolas e diatribes filosóficas. Mas diferem destas porque todos os estudantes são do próprio lugar e os forasteiros não chegam facilmente. Todavia os indigentes não permanecem na pátria, mas vão ao estrangeiro se aperfeiçoarem e depois se estabelecem de boa vontade lá, ao passo que somente poucos retornam à pátria"22. No entanto, esta informação sobre a dificuldade de chegada de estrangeiros deve ser corrigida pela notícia que temos sobre o célebre filosofo itinerante Apolônio de Tiana (ce. 10 a.C. -95 a.C.), que se estabeleceu em Tarso deste muito jovem para ali receber formação intelectual ${ }^{23}$. $\mathrm{O}$ próprio Estrabão nos faz conhecer um grande elenco de filósofos de Tarso, quase todos estóicos ${ }^{24}$, dos quais um foi o preceptor de Otaviano Augusto ${ }^{25}$. A sua importância é acentuada ainda pelo simples fato de que nos anos de 52-51 a.C M.T. Cícero ali passou na qualidade de Procônsul da Cilícia ${ }^{26}$ e pelo fato que Marco Antônio foi para lá após a vitória de Filipos na Macedônia em 42 a.C., e exatamente ali no ano de 41 a.C, ele foi encontrar-se com Cleópatra, que vinha do Egito $^{27}$. Outras notícias sobre a dimensão cultural da cidade chegam até nós do filósofo eclético, pouco posterior ao tempo de Paulo, Dión de Prusa ou Dión Crisóstomo (ce. 45 a.C 115 a.C.), que ali esteve por umas duas vezes e nos deixou dois significativos discursos ${ }^{28}$.

Deste Dión de Prusa encontramos a notícia de uma festa que acontecia em Tarso em honra do deus local Sandon, identificado segundo a "interpretatio graeca" com Heracles (cf. Or. 33,46-47). Mas é completamente ultra-

\footnotetext{
${ }^{22}$ Estrabão, Geogr. 14,5,13. Além do mais, Estrabão acrescenta que Roma está cheia de eridotps provenientes dessa cidade (cf. 14,5,15).

${ }^{23}$ Cf. Filostrato, Vita di Apollonio di Tiana 1,7 (o mestre se chamava Eutidemo da Fenícia).

${ }^{24}$ Cf. Geogr. 14,5,14-15 (= Antípatro; Archedemos; Nestor; 2 de nome Atenodoro; Plutíades; Diógenes; Artemidoro; Diodoro; Dioniside). Veja também, M. Adinolfi, «Tarso, patria di Stoici», in Id., Ellenismo e Bibbia. Saggi storici ed esegetici, Antonianum, Roma 1991, $145-$ 186.

${ }^{25}$ Cf. Estrabão, Geogr. 14,5,14.

${ }^{26}$ Cf. Plutarco, Vit.Cic. 36.

${ }^{27}$ Cf. Plutarco, Vit.Ant. 25-27.

${ }^{28}$ Se trata das Orações denominadas, precisamente, Tarsica prior e Tarsica secunda (= Or. 33 e 34). Com referência, cf. R. Penna, «Le notizie di Dione di Prusa su Tarso e il loro interesse per le lettere di S. Paolo», in Id., Vangelo e inculturazione, 255-274.
} 
passada a tese que queria ver naquela festa um motivo que houvesse influenciado a cristologia pauliana ${ }^{29}$.

\section{O conceito grego de 'inculturação'}

Como se sabe, Paulo define a si mesmo como o "apóstolo dos gentios" (Rm 11,13). Afinal, esta foi a missão para a qual fora designado na estrada de Damasco (cf. Gl 1,15-16) (30 $^{30}$ para a qual se empenhara oficialmente em Jerusalém (cf. Gl 2,9). Isto significa que os destinatários da sua pregação não eram primariamente os Judeus, mas os Não-Judeus, aqueles que logo em seguida seriam chamados latinamente de pagani, mas que ele, em um binômio antitético com Ioudaíoi, prefere denominar Héllēnes, "Helenos\Gregos» (5 vezes: Rm 3,9; 1Cor 1,22.24; 10,32; 12,13; cf. «gregos e bárbaros » em $\mathrm{Rm} 1,14)^{31}$ ou também com o singular coletivo ho Hellen, "O Grego" (5 vezes: $\mathrm{Rm} 1,16 ; 2,9.10 ; 10,12$; G1 3,28); ainda mais freqüentemente, ele designa como Éthnēe, "gentios" (desta forma 45 vezes nas cartas autênticas, das quais 28 vezes somente em Romanos: cf. Rm 1,5.13; 2,14.24; ect), uma denominação que supõe uma evidente pré-compreensão judaica em relação a quem é estranho ao judaísmo, mas que com a qual eram identificados somente os que pertenciam à cultura greco-helênica. A menção dos bárbaroi em $\mathrm{Rm} 1,14$ tem a força retórica de indicar a destinação universal do evangelho segundo o difundido 'topos' da contraposição entre Gregos e Bárbaros documentada em vários autores antigos ${ }^{32}$; historicamente, no entanto, Paulo não saiu do âmbito geo-cultural da área de língua grega". ${ }^{33}$

\footnotetext{
${ }^{29}$ Assim afirmava H. Böhlig, Die Geisteskultur von Tarsos im augusteischen Zeitalter mit Berücksichtigung der paulinischen Schriften, FRLANT 19, Vandenhoeck, Göttingen 1913. Para a crítica, cf. R. Penna, loc.cit., 267-269; e mais: M. Hengel \& A.M Schwemer, Paul between Damascus and Antioch, 167-171 («Pagan and philosophical-rhetorical influences on Paul?»).

30 “A evangelização dos pagãos não representa um corolário concernente a revepalação teofanica ou cristológica, mas sua finalidade própria » (A. Pitta, Lettera ai Galati, SOC 9, EDB, Bologna 1996, 96).

${ }^{31}$ Cf. também At 11,$20 ; 14,1 ; 17,4 ; 18,4.17 ; 19,10 ; 20,21 ; 21,28$.

${ }^{32}$ Cf. H. Windisch, in Grande Lessico del Nuovo Testamento II,89-95.

${ }^{33}$ Ele, na verdade, não andou nem para o Oriente (Mesopotamia e Persia), nem para o Sul (Arábia; Gl 1,17 cf. os comentários), nem na direção Sul-Oeste (Egito e Líbia), e com toda a probabilidade, nem mesmo na direção do extremo Ocidente da Península Ibérica (Quem sustenta que ele tenha andado deve admitir que aquela viagem, além de ter durado "não mais que um verão", tenha sido um fracasso, em virtude da "razão mais provável tenha sido de que o grego não fosse falado de modo geral. Se isso é verdade, o litoral meridional das Gálias e da Itália do norte não teriam sido um campo mais fértil, cf. J. Murphy-O'Connor, Vita di Paolo, Paideia, Brescia 2003, 404).
} 
Devemos também concretamente considerar que as Igrejas às quais eram destinadas as cartas fossem em sua maioria compostas de Gentios de língua grega, mesmo que em Roma os seus leitores devessem ser prevalentemente de tipo judaico-cristã. No capítulo conclusivo da Carta aos Romanos, Paulo fala até mesmo de saudações para o casal Prisca e Áquila da parte de "todas as igrejas dos gentios" (Rm 16,4), sem que jamais em outro lugar contraponha ou aproxime essa referência a uma outra similar: "igrejas dos judeus"! Por isso não deve surpreender se nos seus esforços missionários de "ganhar qualquer um" entre aqueles que são "fora da Lei" (1Cor 9,21), ele devesse necessariamente empregar categorias, conceitos, alusões e notas que fossem familiares a uma audiência não judaica. Sem dúvida esta estratégia fazia parte daquilo que ele entendia quando dizia ter-se tornado "como um que é sem Lei" (1Cor 9,21; cf. Gl 4,12) a fim de poder chegar até aqueles que eram propriamente fora da lei. Certo é que, por exemplo, conceitos como "justiça de Deus, pecado, graça, félobras, promessa, aliança, salvação", para não dizer do que modernamente se entende por escatologia e apocalíptica, eram estranhos à normal pré-compreensão própria da cultura grega. Naturalmente Paulo emprega aos gregos a demonstração de uma fidelidade de base própria da matriz hebraica, e mais, aquelas noções constituem a estrutura portadora da hermenêutica evangélica. Mas ele não para ai neste ponto.

O Apóstolo de fato praticou abundantemente o princípio da adaptabilidade ou condescendência cultural, que hoje chamaremos de inculturação ${ }^{34}$. Isto está denotado claramente no passo clássico de 1Cor 9,19-23 ("Sendo inteiramente livre, me fiz escravo de todos para ganhar o número maior possível..."), além de Rm 14,1 - 15,13 (sobre a relação entre fortes e fracos). Ora, este critério pertence ao conceito de sygkatábasis (em latim condescensio), "condescendência, adaptação", que é próprio da tradição grega ${ }^{35}$. Mesmo precisando que tal prática não se identifica com o caráter e o comportamento do kólax (adulador), que, ao contrário, é condenado por muitos escritores gregos ${ }^{36}$, sustenta-se que a sygkatábasis deve ser realizada com medida, como se lê, por exemplo, em Epíteto: "Quem desce com freqüência para o contato (sygkathiéta) com os outros

\footnotetext{
${ }^{34}$ Cf. R. Penna, «Cultura/Acculturazione», in Nuovo Dizionario di Teologia Biblica, a cura di P. Rossano, G. Ravasi, A. Girlanda, San Paolo, Cinisello Balsamo 1988, 345-357.

${ }^{35}$ Cf. M. M. Mitchell, «Pauline Accomodation and 'Condescension' (synkatábasis): 1Cor 9:19-23 and the History of Influence», in T. Engeberg-Pedersen, ed., Paul Beyond the Judaism/Hellenism Divide, 197-214; C.E.Glad, «Paul and Adaptability», in J.P. Sampley, Paul in the Greco-Roman World, 17-41; C.E. Glad, Paul and Philodemus, 185-332.

${ }^{36}$ Cf. Aristóteles, Et.Eud. 1221a7; Teofrasto, I caratteri II; Plutarco, Quomodo adulator ab amico internoscatur (= Mor. 48e-74e); sobre Filodemos, cf. E. Kondo, «Per l'interpretazione del pensiero filodemeo sulla adulazione nel PHerc. 1457», Cronache Ercolanesi 4 (1974) 4356.
} 
deverá necessariamente ou igualar-se a eles (ekeinois exomoiōthênai) ou transportá-los ao próprio nível (ekeinous metatheînai epì tà autoû). De fato, se se coloca um carvão meio apagado perto de um que está queimando, ou aquele apagará este ou este acenderá aquele... Pelo motivo de que o risco é alto, será necessário ser muito circunspeto no ato de ser condescendente (eulabôs dề sygkathiesthai) nestas relações similares..." ${ }^{\text {'37 }}$. A aplicação deste critério, além da retórica $^{38}$, dava-se sobretudo a propósito de alguém que pertencia à classe social alta que se inclina na direção de quem estava mais em baixo ${ }^{39}$. Uma especificação diz respeito à condescendência divina, como se pode ler em Fílon de Alexandria a propósito do sonho de Jacó acerca da escada com anjos que subiam e desciam: "Sobem e descem as palavras divinas: quando sobem levam a alma consigo..., quando descem o fazem para condescender com amor e misericórdia (sygkatabaínontes dià filantrōpian kaì éleon) ao nosso gênero"40. Eis por exemplo o que escreverá Clemente de Alexandria sobre a adaptação de Paulo segundo a passagem de 1Cor 9,19-23: "Aquele que condescende a esta adaptação para a salvação do próximo (somente para a salvação daqueles para os quais se adapta) não está fazendo nenhum ato de fingimento... não sofre nenhuma constrição. Somente pelo bem do próximo fará certas coisas, que de modo algum haveria feito antes, se não por amor a eles: isto como exemplo para quantos conseguem suceder a Paulo na sua tarefa de educar, amigo dos homens e amigo de Deus; isto para mostrar a verdade das suas palavras, para fazer com que o amor ao Senhor fosse sempre ativo" 41 .

Não deve causar espanto se o Apóstolo praticou uma synkatábasis também a nível cultural e precisamente ter assumido determinados conceitos do mundo grego, ao qual pertenciam os seus normais destinatários. Isto pode ser constatado, seja em relação ao estoicismo, seja a temas sobre várias matérias, seja provavelmente até mesmo no âmbito propriamente religioso.

\footnotetext{
${ }^{37}$ Epitteto, Diatr. 3,16,1-3 (onde o verbo sygkathiēmi resulta sinônimo de sygkatabaínō). In Ib. 2,9,19-22 Epitteto, a despeito, identifica o Judeu com quem não deflete das próprias convicções.

${ }^{38}$ Cf. Cícero, De oratore 1,31,138: «Primeiro dever do orador é falar de modo próprio a persuadir (ad persuadendum accomodate)».

${ }^{39}$ Cf. Políbio 26,1.3 (in Ateneu, Deipnosofisti 5,193d: a propósito de Antíoco Epífanes).

${ }^{40}$ Somn. 1,147. Fílon de Alexandria também usa o termo eterómorfos para indicar as diversas manifestações de Deus, que conversa com os homens como um amigo com os amigos (cf. De somn. 1,232-233). Mas o tema da sugkatábasis será desenvolvido propriamente no âmbito patrístico-cristão (cf. K. Duchatelez, «La 'condescendence' divine et l'histoire du salut», NRT 95 [1973] 593-621).

${ }^{41}$ Clemente de Alexandria., Stromati 7,9 (53,4-5).
} 


\section{Paulo e o estoicismo}

Existe mais um sinal da presença de qualquer eco da filosofia estóica nas cartas de Paulo ${ }^{42}$. Os princípios desta escola, de fato, por sua natureza não estão distantes de alguns elementos próprios do cristianismo, se apenas observamos o que escreve Sêneca: "Nenhuma escola é mais benévola e gentil (benignior leniorque), nenhuma mais amante dos homens (amantior hominum) e mais atenta ao bem comum (communis boni attentior), desde modo seu objeto declarado é de ser de utilidade e de ajuda (usui essere et auxilio) e de considerar não somente o interesse individual, mas o interesse de cada um e de todos (universis singulisque)" (Clem. 2,5,2-3) ${ }^{43}$. A clássica monografia de Engberg-Pedersen fez uma investigação aprofundada desta presença estóica nas cartas ao Filipenses, aos Gálatas e aos Romanos, mesmo que seja mais indulgente com as semelhanças do que com as diferenças $^{44}$. Deve-se dizer com toda certeza que Paulo não é, de modo algum, um representante do estoicismo, um pequeno mais significativo sinal desta diferença se vê no uso quase inexistente do conceito de aretēe, "virtude", que ele emprega uma só vez (em Fl 4,8), em um texto, contudo, formulado em termos axiomáticos, enquanto o estoicismo já com Zenão de Cízio a exalta até mesmo como o "sumo bem" ${ }^{45}$ e a identifica com a felicidade ${ }^{46}$.

\footnotetext{
${ }^{42}$ Eventuais componentes do pensamento de Paulo que reconduzem a esquemas próprios do cinismo (cf. F.G. Downing, Cynics, Paul and the Pauline Churches. Cynics and Christian Origins II, Routledge, London 1998), podem ser inseridos perfeitamente no âmago da prospectiva estóica. De fato, mesmo tendo em conta que os "Cínicos dexenvolvia sua própria atividade nos carros e nas estradas dos campos, como pregadores e cosoladores dos membros das classes inferiores, ..., aquela que eles difundiam como 'filosofia cínica', na verdade não era outra coisas que um estoicismo mais grosseiro... De resto, as diferenças tendiam tanto mais facilmente a resignar-se enquanto também alguns Estóicos se sentiam chamados a assistir espiritualmente infelizes e oprimidos... Epíteto transfigurava o Cínico ideal em um meio de Deus...» (M. Pohlenz, La Stoa. Storia di un movimento spirituale, Bompiani, Milano 2005, 583-584).

${ }^{43}$ Cf. T. Engberg-Pedersen, «Paul, virtues, and vices», in J.P. Sampley, Paul in the GrecoRoman World, 608-633.

${ }^{44}$ Cf. T. Engberg-Pedersen, Paul and the Stoics, cit.; Id., «Stoicism in Philippians», in Id., Paul in His Hellenistic Context, 256-290. Sobre as diferenças, a propósito de Rm 12, insiste demais Ph.F. Esler, «Paul and Stoicism: Romans 12 as a Test Case», NTS 50 (2004) 106-124; na polêmica com este autor, se demonstra, contudo, bastante mais equilibrado, R.M. Thorsteinsson, «Paul and Roman Stoicism: Romans 12 and Contemporary Stoic Ethics», JSNT 29 (2006) 139-161 specie 147-159.

${ }^{45}$ In $S V F$ I,47,187.

${ }^{46}$ In SVF I,47,189; cf. também Crispo, em SVF III,16,66.
} 
Vejamos então mais em detalhes e em síntese, sem presumir o esgotamento da matéria ${ }^{47}$, alguns pontos que de fato constituem um evidente terreno comum entre as duas partes.

4.1. Em primeiro lugar chamo a atenção para aqueles textos nos quais o Apóstolo define a comunidade cristã e especialmente cada um dos cristãos individualmente como templo-habitação de Deus (cf. 1Cor 6,19: "Não sabeis que o vosso corpo é templo do Espírito Santo, que reside em vós e que o recebestes de Deus"). É bem verdade que a imagem do templo aplicada à comunidade inteira (cf. 1Cor 3,16,17b) não é estóica, mas encontra-se em Qumran (cf. 1QS 8,5;11,8s), mas propriamente estóica é a idéia de uma presença ou inabitação de deus em cada homem individualmente. De fato, isto se pode ler em claras letras em muitos autores, isto é, em Sêneca ${ }^{48}$, em Epíteto $^{49} \mathrm{e}$ em Marco Aurélio ${ }^{50}$. Obviamente a diferença está na concepção deste hóspede interno, que para os estóicos é o logos racional ao passo que para Paulo é o Espírito Santo (cf. também 2Cor 1,22; Gl 4,6). Pode-se concluir, portanto, que uma presença divina no individuo é de fato análoga.

4.2. Típico ideal estóico é a autárcheia, isto é, a faculdade de dispor autonomamente de si mesmo sem depender das circunstâncias exteriores. Paulo condivide este ideal e o diz com clareza em 1Ts 4,12 ("Não tens necessidade de ninguém") e em Fl 4,11-12 ("Aprendi a mim bastar a mim mesmo [autárchēs eînai] em toda ocasião: aprendi a ser pobre e aprendi a ser rico. Estou plenamente iniciado em tudo; à saciedade e à fome; à abundância e à indigência"). Analogamente Epíteto diz de si mesmo: "Sou um sem casa, sem cidade, sem bens, sem escravos; o meu leito é a terra; não tenho mulher; não filhos; não uma caixinha, mas a terra somente e o céu e um único manto. E mesmo assim, o que me falta? (Epíteto - Diatr. 3,22,47). O mesmo concei-

\footnotetext{
${ }^{47}$ Por exemplo, sobre o conceito tipicamente estóico da diferença (não obstante em Paulo falte o lexema específico), cf. W. Deming, «Paul and indifferent things», in J.P. Sampley, Paul in the Greco-Roman World, 384-403; sobre o seu valor no estoicismo, cf. M. Pohlenz, La Stoa. Storia di un movimento spirituale, 245-249.

${ }^{48}$ Cf. Epist. 41,1-2: «Deus está próximo de ti, está contigo, está dentro de ti (prope est a te deus, tecum est, intus est) ... Em nós mora um espírito divino (sacer intra nos spiritus sedet), que vigia e observa o mal e o bem que fazemos».

${ }^{49}$ Cf. Diatr. 1,14,14s: «Quando fechais a porta e apagais a lâmpada, não digais nunca que estais sós: não estais, realmente, mas Deus está no vosso íntimo (ho theòs éndon esti), e é o vosso "daimonion"»; 2,8,14: «Deus mesmo, no teu íntimo, tudo observa e tudo escuta».

${ }^{50} \mathrm{Cf}$. Ric. 3,4: «Um homem que não ouse meter-se entre os ótimos é igual a um sacerdote... que se dedica ao culto daquela divindade que está nele » (cf. 3,5: «Aquele deus que está em [ho en soì theós] ti, te guie...»). Veja também Menandro, Monostichoi 107: «La coscienza è Dio per tutti i mortali»!
} 
to paulino é expresso por Marco Aurélio quando afirma de ter aprendido a "ter necessidade de poucas coisas e a fazer tudo por si mesmo (sozinho)" (Ric. 1,5: tò oligodeès kaì tò autourgikón). As palavras de Paulo então enfatizam, nem mais e nem menos, aquelas dos estóicos ${ }^{51}$.

4.3. Afim a esta temática é o conceito de hypomonē, "paciência, capacidade de suportar" (Rm 5,3.4; 8,25; 15,4.5; 2 Cor 1,6; 6,4; 12,12; 1Ts 1,3). Trata-se de uma atitude típica da filosofia estóica, tanto que Sêneca lhe dedicou um inteiro tratado: De constantia sapientis, "A firmezalinalterabilidade do sábio". Nisto o filósofo exprime-se com os belíssimos sinais de um ascetismo, que terá notáveis influxos sobre a sucessiva espiritualidade cristã. É dito que o sábio que diz ser ele como um rochedo, contra o qual quebram as ondas mais ameaçadoras sem que isso lhe provoque algum $\mathrm{mal}^{52}$."Ele suporta todas as coisas, os rigores do inverno, as intempéries, a febre, a doença e todas as outras circunstâncias que a sorte lhe traz... Ele pertence à categoria dos atletas, que com o longo e constante exercício conseguem adquirir a força de suportar e de enfrentar todos os ataques dos inimigos" $(9,1.5)$. Tudo isto é possível na medida em que o sábio "fundamentado na razão (ratione innixus) passa através das vicissitudes da vida humana com o ânimo divino" $(8,3)$. Eis a exortação conclusiva: "Defende o lugar que a natureza lhe ofereceu. Tu perguntas que lugar é este? O lugar do homem!" $(19,4)^{53}$. Aquilo que distingue o Apóstolo são as motivações que não residem sobre a razão, mas se fundamentam sobre os dados da fé e na esperança de assimilação a Cristo e da inabitação do Espírito ${ }^{54}$.

4.4. Em Rm 1,24-31, Paulo enumera uma série de vícios tidos como conseqüência da idolatria como falso conhecimento da verdadeira identidade de Deus pelos homens. Por três vezes (vv. 24.26.28), ele afirma, em termos repetitivos, que "Deus os entregou" a uma série de paixões desordenadas que

\footnotetext{
${ }^{51}$ Mais genericamente, sobre a filosofia moral da idade imperial, cf. Teresa Morgan, Popular Morality in the Early Roman Empire, University Press, Cambridge 2007.

${ }^{52}$ A imagem é encontrada em Marco Aurelio, segundo o qual é necessário «assemelhar-se ao rochedo, contra o qual se lançam continuamente as ondas, mas esse permanece firme e em volta dele acomoda o reboliço das águas» (Ric. 4,49).

${ }^{53}$ Ainda mais famosa é a fórmula lapidar atribuída a Epiteto, como sinal e síntese de toda a moral estóica, anunciada com outra terminologia, mas de igual significado: Substine et abstine, «suporta e resiste» (em grego, anéchou kaì apéchou: Aulo Gellio, Notti attiche 17,19; segundo esse autor, além de Epitteto, «costumava dizer que os dois defeitos de grande sofrimento mais graves e desprezíveis são a falta de compaixão e a intemperança»).

${ }^{54}$ Cf. R. Penna, «La forza della pazienza (hypomonē) in Paolo», Parola Spirito e Vita 55 (2007,1) 139-149.
} 
vão desde a homossexualidade até a falta de misericórdia. Deste modo, evidentemente, Deus realiza um juízo sobre uma ampla variedade de pecadores. E o que chama atenção é o fato de que este juízo, muito ao contrário de ser adiado para um futuro escatológico (assim se dará comente na seção sucessiva: Rm 2,1-11), se realiza no fato mesmo do comportamento imoral e depravado, próprio dos viciados. Ora, transparece aqui um conceito tipicamente estóico. Este é o princípio, segundo o qual, assim como a virtude é prêmio em si mesma, do mesmo modo o vício é castigo em si mesmo. Exatamente isso, podemos ler em Sêneca: "A máxima punição dos delitos está nestes delitos mesmos" (Epist. 87,24: maximum scelerum supplicium in ipsis est) ${ }^{55}$. Este enunciado estóico se fundamenta em premissas fundamentais. Assim escreve Pohlenz: "A ética grega deduz a moralidade unicamente da physis do homem... e faz abstração de qualquer poder superior pudesse regular o seu agir de fora... Um Zeus que com decálogo próprio criasse a moralidade seria inconcebível para os Gregos" ${ }^{" 56}$. O homem grego, de fato, fundamenta a moralidade sobre a lei da natureza e no logos inerente ao homem ${ }^{57}$. O fato que Paulo em Rm 1,24-31 não faça nenhuma referência a um juízo divino metahistórico, além de colocar uma questão sobre dependências redacionais da carta, é sinal que, pelo menos nesta seção, ele depende de um background cultural extra-judaico.

4.5. Aquilo que Paulo diz da comunidade cristã como soma, "corpo" (Rm 12,4-5: "um só corpo em Cristo"; 1Cor 12,27: "vós sois o corpo de Cristo"), encontra, na filosofia estóica, claras equivalências ${ }^{58}$. A definição não pertence, com toda certeza, não pertence à tradição judaica, porque na ótica de Israel não se podia e não se pode absolutamente falar de um "corpo de Cristo, isto é, do Messias" e muito menos de um "corpo de Adonai, isto é, de JHWH"

\footnotetext{
${ }^{55}$ Sêneca continua: «Te enganas se remetes a punição ao carnífice ou ao cárcere: os delitos devem ser punidos não logo após terem sido cometidos, mas enquanto são praticados» (Epist. $87,25)$.

${ }^{56}$ M. Pohlenz, La Stoa. Storia di un movimento spirituale, 272.

${ }^{57}$ Por isso, segundo Ario Didimo, pode ser desresponsabilizado aos deuses só aquilo que é contra a virtude (in Stobeo II,105-106). De resto, já Zenão sentenciava que «nada é mau senão aquilo que é moralmente torpe e vicioso» (SVF I,46,185).

${ }^{58}$ Cf. R. Penna, «La chiesa come Corpo di Cristo secondo S. Paolo. Metafora socialecomunitaria o individuale-cristologica?», Lateranum 68 (2002) 243- 257.

${ }_{59}$ Deve ser lembrado o misticismo do Shiur qomah, «medida do corpo», atestado em uma sucessiva corrente da idade rabínica (o mais antigo manuscrito é do séc. X) e consistente na descrição da amplitude do «corpo do criador» a dimensão cósmica (cf. P. van der Horst, «The Measurement of the Body. A Chapter in the History of Ancient Jewish Mysticism», in D. van der Plas, ed., Effigies Dei. Essays on the History of Religions, Leiden 1987, 56-68, com tradu-
} 
eventualmente exista em nível de comparação um sintagma análogo àquele em questão a nível extra-textual ${ }^{60}$. Para se atingir este objetivo é necessário evitar (coisa que quase sempre não é feita) aqueles casos em que o conceito de corpo é utilizado apenas em forma genérica ou absoluta, ou também em relação a uma totalidade, por exemplo, quando Crísipo define respectivamente uma assembléia, um exército e um coro como se cada um fosse um "corpo só" (hèn soma) ${ }^{61}$. Mais propriamente, podem entrar nesta lista somente aqueles casos em que o termo "corpo" é constituído de um modo como termo regente de um específico genitivo de especificação. Mas os tipos de corpo são muitos, e o estoicismo em particular, enumera mais de um $^{62}$. Assim é necessário ainda excluir seja a referência ao corpo morto de uma pessoa $^{63}$, visto que Paulo de toda forma como uma entidade vivente, seja o seu uso como simples perífrase para indicar uma qualquer pessoa individu$\mathrm{al}^{64}$ viva, seja também a sua associação a um termo abstrato ${ }^{65}$.

Faz-se necessário, ao contrário, observar eventuais designações de um conjunto, possivelmente de uma coletividade em quanto dependente de uma pessoa precisa ou de alguma forma relacionada com ela, de tal modo que

ção do texto e bibliografia). É possível que essa especulação corresponda a outras de origens pagãs.

${ }^{60}$ Veja a ampla e fundamental documentação em E. Schweizer, $\sigma \hat{\omega} \mu \alpha \kappa \tau \lambda$, GLNT XIII, 611659 .

${ }^{61}$ SVF II, p. 124, 367. Sobre essa linha, veja também o célebre dito de Sêneca, a propósito de nossa inserção no mundo: Membra sumus corporis magni, «Somos membros de um grande corpo» (Epist. 95,52; cf. 92,30). A esse usso pertence tamb[em o genitivo apexegético usado por Platão: «o corpo do universo» (Tim 31B: tò toû pantòs sôma), «o corpo do cosmos» (ib. 32,c: tò toû kósmou sôma). Analogamente Fílon de Alexandria afirma que o cosmos é «o maior dos corpos, tò mégiston sōmátōn, e esse contem no próprio seio a multidão dos outros copros como seus próprios membros, hōs oikeîa mérē» (Plant. 7).

${ }^{62}$ Seneca, seguindo a tradição estóica, individualiza três tipos (corpora continua, composita, ex distantibus): «Alguns corpos são contínuos como é o homem; outros compostos, como um navio, uma casa e todos aqueles cujas partes são unidas mediantes ajustes; outros são constituídos de elementos descontínuos e as suas partes permanecem separadas, como um exército, um povo, o senado, em fim, os elementos dos quais tais copros resultam, estão unidos por lei ou por ofício, contudo, por natureza são divisos e cada qual está por si» (Epist. 102,6).

${ }^{63}$ Além de Platone (cf. Repubbl. 469d: «É coisa inconhecível.... reter inimigo o corpo dritenere nemico il corpo di chie quem está, tò sôma tô̂ tethneōtos»), cf. também Mc 15,43 onde se conta de José de Arimatéia que pediu a Pilatos «o corpo de Jesus», e analogamente em Lc 24,3 segundo o qual as mulheres no sepulcro «não encontraram o corpo do Senhor Jesus».

${ }^{64}$ Cf. Eurípides, Medea 1108: «um filho (sôma...téknōn) está junto à flor da juventude»; Eródoto 1,32,8: «uma pessoa sozinha (anthrópou sôma hén) não é de fato suficiente a si mesmo».

${ }^{65}$ Cf. «o corpo do pecado» (Rom 6,6: tò sôma tês hamartías) ou «o corpo da morte» (Rom 7,24: tò sôma tô̂ thanátou). 
especifique o corpo com um genitivo. Ora, sabe-se que uma construção deste gênero existe para exprimir uma dupla semântica: a nível cósmico para indicar o universo e a nível político para indicar a sociedade cívica. O primeiro nível, atestado em textos órficos de difícil datação, descreve o cosmos como um corpo imenso identificado com Zeus (cf. fragmentos órficos168,12.24: "Todas estas coisas (fogo, água, terra, ar, noite e dia) se encontram no grande corpo de Zeus [Pánta gàr em Zenòs megalo, táde somati keîtai], ... corpo radiante, indestrutível, imenso"). Pode ainda indicar as várias partes como "membros" de um deus (cf. hinos órficos 11,3: aqui, depois de ter definido o deus Pã como "totalidade do mundo", o céu, a terra, o fogo são definidos como membros do mesmo Pã [táde gár mele estì ta Panos]. No hino 66, os mesmo elementos são considerados membros de Efesto") $)^{66}$. A nível político, de outro modo, uma interessante construção análoga àquela paulina é encontrada em um dialogo do estóico Sêneca, no qual o filósofo se dirige a Nero declarando ser ele nada mais nada menos que: "Tu és a alma da tua república e ela é o teu corpo (tu animus rei pubblicae tuae es, illa corpus tuum) ${ }^{\prime \prime 67}$, onde a expressão "o teu corpo" com o adjetivo possessivo equivale de fato a dizer que Nero tem aqui o seu próprio corpo (o corpo de Nero). A distinção que Sêneca faz entre animus e corpus é sem dúvida muito interessante, mas em todo caso o tom do conjunto do texto é celebrativo e encomiástico. $\mathrm{O}$ filósofo, escrevendo no ano de 56, quer mesmo fazer o elogia da clemência de Nero (aquele dos primeiros anos), que enquanto príncipe "é o laço graças ao qual todo o conjunto da coisa pública permanece coeso" (vinculum per quod res publica cohaeret $)^{68}$.

Uma coisa é certa: o sintagma paulino não pretende etiquetar nem uma dimensão cósmica nem um conjunto político, e além do mais não é de forma alguma laudatório. No entanto é necessário perguntar de que modo Paulo chegou a uma definição assim tão nova e, sobretudo, o que mesmo que esta expressão significa. Para isso seria necessário aprofundar alguns dados cristológicos típicos da fé cristã, que aqui teremos de deixar de lado. Mas em

\footnotetext{
${ }^{66}$ Recordemos aqui que o texto citado por Frammenti orfici se encontra em Eusébio de Cesaréia, Praep. Evang. 3,9 (e é atribuído a Porfírio), enquanto os Inni orfici são uma coletânea da qual já fala Pausânias no séc. II d.C. $(9,30,12)$, mas que não esclui junções sucessivas. Há quem sintetize essa conseção sob o rótulo de «Allgott als Makroanthropos», isto é, do Deus universal como macro-homem (cf. K.M. Fischer, Tendenz unf Absicht des Epheserbriefes, FRLANT 111, Vandenhoeck, Göttingen 1973, 68-75).

${ }^{67}$ Seneca, De clementia $1,5,1$.

${ }^{68} \mathrm{Um}$ pouco mais adiante, no mesmo parágrafo, referindo-se a Nero, escreve: «Guarda-te a ti mesmo quando pareces estar guardando algum outro. É mister preservar também alguns cidadãos reprováveis, assim como se preservam os membros doentes »!
} 
todo caso um paralelismo pelo menos formal com o âmbito estóico é inegável.

4.6. Ainda falta considerar um aspecto do estoicismo, cujo o influxo sobre o Apóstolo Paulo é talvez o mais consciente. Trata-se do universalismo e dos seus desdobramentos sobre a concepção do homem e da sociedade. É necessário recordar que Paulo vive em uma sociedade já desde muito tempo globalmente marcada pela obra de Alexandre Magno, e que esta, pelo menos segundo a nobre interpretação oferecida por um escritor como Plutarco, um pouco posterior ao nosso Apóstolo, foi profundamente caracterizada de fatores combinados de universalismo e de unitariedade irrevogável introduzidas pelo macedônio no modo comum das pessoas pensarem. Eis o que escreve Plutarco:

"(Alexandre) acreditando ter vindo como enviado divino (theóthen), harmonizador e reconciliador de todas as coisas (...) conduz a unidade as coisa mais dispares, misturando como em uma grande taça as vidas e os costumes e os matrimônios e os modos de viver; ele ordenou que todos tivessem com pátria a totalidade da ecumene (o mundo grego), (...) que os bons fossem considerados conterrâneos e os malvados fossem tidos como estrangeiros, e que o Grego e o Bárbaro não se distinguissem nem pelo manto, nem pelo escudo, nem pela espada, nem pela capa, mas que o grego se demonstrasse tal por sua virtude e o bárbaro por sua maldade (...) Ele quis fazer com que tudo sobre a terra se sujeitasse a uma única lei e a uma única cidade (henòs lógou kaì mías politeías) e que todos os homens se mostrassem como um só povo (héna dêmom). A este objetivo, ele se moldava a si mesmo. E se a divindade que havia enviado aqui em baixo a alma de Alexandre não o tivesse chamado assim tão cedo, uma só lei governaria todos os homens e estes observariam uma só norma de justiça como uma luz comum; em vez disso, aquela parte da terra que não viu Alexandre ficou privada da luz do sol. De fato, o primeiro objetivo da sua expedição o revela como um filósofo, que não busca para si delicias e opulência, mas para todos os homens concórdia e paz e comunhão uns com os outros (homónoian kaì eirēnēn kaì koinōnian pròs allēlous $)^{69}$.

\footnotetext{
${ }^{69}$ Plutarco, De Alexandri Magni fortuna aut virtute 6.8.9 (= Mor. 329 CD, 330 DE); cf. L. Canfora, Ellenismo (BCM 944), Roma-Bari 1987, 45s. Um outro personagem muito mais próximo no tempo, Cézar Augusto, merecia elogios análogos, os quais lhe são atribuídos por Fílon de Alexandria, por «ter amansado e ajustado em harmonia todos os povos selvagens, ... ter acrescido a Elída de muitas outras Elíadas... fazendo guardião da paz, etc. » (Filone, Leg. ad C. 146-147). Cf. também R. Penna, «L'immagine di Roma in Filone Alessandrino in Flaccum e Legatio ad Caium», in: P. Catalano - P. Siniscalco (a cura), Roma fuori di Roma:
} 
Certo é que, como escreveu o Wendland no início do século XX, a ampliação do horizonte político e geográfico gerou um vivo interesse pelos povos estrangeiros, a tal ponto que enfraqueceu, se não até mesmo eliminou, a orgulhosa autoconsciência nacional que tempo atrás, após as guerras persas, determinou na Grécia a drástica oposição aos bárbaros ${ }^{70}$.

Foi a filosofia estóica que recebeu e desenvolveu amplamente estas premissas. Como bem se exprime Pohlenz, "uma rápida marcha triunfal levou a Estoa a uma posição de primado na vida espiritual do Oriente. (Esta) se fez intérprete do novo sentimento da vida helênica, proclamou a idéia de uma humanidade em que os membros são todos unidos uns aos outros por uma inclinação natural e anunciou um novo ideal, que impunha ao homem os seus deveres para com seus iguais, mas ao mesmo tempo o liberava de todos os laços físicos e nacionais e fazia dele um ser puramente espiritual" (Pohlenz) ${ }^{71}$. O homem passava a ser parte de uma ampla comunidade supra-nacional, na qual dominava o simples princípio da obediência à lei natural. No âmbito judaico, é, sobretudo, Filón de Alexandria que demonstrou de modo mais pleno em suas obras o influxo das idéias estóicas, além das platônicas. Mesmo que seja debatida a questão de como deva ser rotulado o filósofo hebreu como estóico, platônico, eclético ou outra coisa ainda ${ }^{72}$, a presença de idéias estóicas nas suas obras, sobre as quais não podemos nos deter, não é somente indubitável, mas realmente bem consistente $^{73}$. Sem dúvidas é estoicizante aquilo que escreve a propósito do homem quando o define como "cidadão do mundo" (kosmopólitos $)^{74}$.

istituzioni e immagini (Da Roma alla Terza Roma-Studi V), Università degli studi "La sapienza", Roma 1994, 45-57.

${ }^{70}$ Cf. P. Wendland, La cultura ellenistico-romana nei suoi rapporti con giudaismo e cristianesimo (Biblioteca di storia e storiografia dei tempi biblici 2), Paideia, Brescia 1986 (or. ted., Tübingen $1972^{4}, 1912^{1}$ ), 62. Veja também M. Hengel, Ebrei, Greci e Barbari. Aspetti dell'ellenizzazione del giudaismo in epoca precristiana (SB 56), Paideia, Brescia 1981 (or. ted., Stuttgart 1976), 111-136.

${ }^{71}$ H. Pohlenz, La Stoa. Storia di un movimento spirituale, 535 e 565-566. Cf. também M. Spanneut, Permanence du Stoicisme. De Zénon à Malraux, Gembloux 1973, 110-111.

${ }^{72}$ Veja o bom status quaestionis de base traçado por R. Arnaldez, «Introduction generale», in: Id., De opificio mundi (Les Oeuvres de Philon d'Alexandrie 1), Les Belles Lettres, Paris 1961,70-96.

${ }^{73}$ Exemplificando, pode-se acenar às seguintes noções: a função do Logos, a providência divina que dá uma organização final ao universo, o homem como microcosomos, o mundo como cidade e sua organização como constituição da cidade, a teoria da paixão e da virtude, o dever do homem de obeder a lei racional que lhe indica o caminho da vida e o exercício da virtude, etc.

${ }^{74}$ Filone Al., Opif. 1. 
No que se refere à específica doutrina do universalismo, ela pode ter certamente raízes e conotações do tipo cínico ${ }^{75}$, mas termina por contradistinguir tipicamente da escola estóica, em parte pelo fato de que grande parte dos filósofos do Pórtico foram de origem não grega. Se alguns estudiosos negam estas idéias no que diz respeito à Estoa Antiga de Zenón de Cizio $^{76}$, estas idéias são características de Crispo e particularmente da Média Estoa de Posidônio ${ }^{77}$. Este último define sintomaticamente o cosmos como "um sistema de deuses e homens e de tudo aquilo que acontece como obra deles" 78 , isto sugere a idéia de um sýndesmos, um vínculo, que une unitariamente todos os seres entre $\mathrm{si}^{79}$. Até mesmo um poeta como Melagro de Gadara, natural da trans-Jordânia palestina (ce. 140 - 70 a.C.), sabia que era totalmente indiferente a sua origem semítica: "Mesmo que seja um sírio, que importa? Nos habitamos o mundo, o estrangeiro, como se fosse uma única pátria" ${ }^{" 80}$. Isto é ainda mais explícito na Estoa da idade imperial, e especialmente em Sêneca. Ninguém como ele sublinhou tanto a igualdade entre os homens, como quando escreveu: "a virtude é possível a todos, e todos por

\footnotetext{
${ }^{75}$ Essa constatação é fortemente sublinada por F.G. Downing, «Cynic Preparation for Paul's Gospel for Jew and Greek, Slave and Free, Male and Female», NTS 42 (1996) 454-462. Efetivamente, ao que parece, já Diógenes de Sinope, «interrogado de onde era, respondeu: kosmopolitēes» (Diog.L., Vit.phil. 6,63). Mas, antes ainda, leiamos a propósito de Aristipo de Cirene, iniciador da escola edonistica, que, por não submeter-se as regras da polis e, por consequencia, não condividir posições nem de comando, nem de escravidão, buscava a plena liberdade individual no sentir-se «forasteiro em qualquer lugar» (Chenofonte, Memor. 2,1,13: xénos pantachoû eimi).

${ }^{76}$ Cf. M. Isnardi Parente, Lo stoicismo ellenistico (I filosofi 59), Laterza, Roma-Bari 1993, 39-40. Contrariamente a interpretação que nos dará Plutarco, la Politeia di Zenone «é um modelo teórico da cidade sem barreiras que nada tem a ver com a obra da unificação étnica projetada, e em parte cumprida, por Alexandre: tal ausência de barreiras não diz respeito aos homens, em geral, nem mesmo aos povos, mas aos sábios, que de tal cidade perfeita são os únicos e verdadeiros cidadãos » (39).

${ }^{77}$ Segundo Crísipo, «o cosmos é governado segundo o intelecto e a providencia» (in: Diog.L., Vit.phil. 7,138 = SVF 11,634) e «as nossas naturezas individuais são parte daquela universal» (in: Ibid. 7,87 = SVF 111,4). Ainda mais, segundo Posidônio, existe uma syn-géneia entre as espécies humanas (o tema é já acenado por Ésquilo, Pers. 185-186, onde a Grécia e a bárbara Ásia aparecem como uma dupla de irmãs da mesma raça), que são guiadas, não tanto da Týche quanto da Prónoia divina; essa, ainda mais positivivamente da outra, a qual permite que povos na obscuridade possam emergir das sombras para tornar-se dominadores dos outrso povos famosos e potentes (como os Macedônios no confronto com os Persianos, ou como os Romanos nos confrontos com a Grácia e dos reinos helenísticos): Esses funcionam quase como instrumentos e causas do governo providencial do cosomos, que é, como uma sõ cidade sapiencialmente correta. Cf. Isnardi Parente, Lo stoicismo ellenistico, 104-105 e 149-151.

${ }^{78}$ In: Diog.L., Vit.phil. 7, 138.

${ }^{79}$ Cf. É. des Places, Syngéneia. La parenté de l'homme avec Dieu d'Homère à la Patristìque, Klincksieck, Paris 1964, 145-149.

${ }^{80}$ Anth. Graeca VII, 417,5-6 (e continua: «l'unico Caos ha generato tutti i mortali»).
} 
isso são nobres" ${ }^{\prime 1}$. Mesmo sendo verdadeiro que seu discurso sobre isso seja exemplificado recorrendo às disparidades internas à sociedade (entre cavalheiros, livres e escravos ${ }^{82}$, mais que a diversidade entre bárbaros ou entre os povos em geral. Todavia, ele fala dos homens sem qualquer distinção, quando, perguntando-se sobre quais normas pode fornecer para o comportamento dos homens, assim se exprime:

"Posso brevemente ensinar a seguinte norma à qual deve ater-se o homem no cumprimento do seu dever: Tudo o que tu vês, em que está contido juntamente o divino e o humano, constituem uma só coisa; são membros de um só grande corpo (omne hoc quod vides... unum est, membra sumus corporis magni). A natureza nos gerou ligados por estreitos laços de íntima parentela (cognatos), porque somos formados dos mesmos elementos e tendemos ao mesmo fim. A natureza nos inspirou um amor recíproco e nos fez sociáveis (...) Esteja sempre em nossos corações e em nossos lábios aquele famoso verso: "Sou um homem, e nada de humano considero estranho") ${ }^{83}$.

Esta mesma concerne ao homem como cidadão do mundo, e então superior a todo particularismos de qualquer espécie, é encontrada também em Epiteto e em Marco Aurélio ${ }^{84}$.

É por fim muito fácil tomar e colocar sobre a mesmo linha também alguns passos das cartas paulinas, que se mostram objetivamente paralelos. Nenhum comentário deixa de anotar este fato. Isto se pode constatar, não somente onde o Apóstolo fala da comunidade dos batizados como um único corpo de Cristo, mas, sobretudo, lá onde Paulo nega qualquer distinção entre Gregos e Bárbaros (cf. Rm 1,15) ou entre Judeu e Grego (cf. Rm 3,9; 1Cor 13,13; Gl 3,28; Cl 3,11). O fato que não pode ser contradito é que o vínculo pretendido pelo Apóstolo não é aquele da comunhão de natureza, mas aquele do batismo e da fé comum em Cristo. Mesmo que estejam bem distantes estes dois pontos de vista, mas mesmo assim, ao menos formalmente, mantém-se a mesma ótica. Por fim, o efetivo empenho apostólico empregado por Paulo demonstra suficientemente a evidência de que para ele entre os homens "não existe nenhuma distinção" (Rm 3,22.29; 10,12)! Esta sua "tolerante indife-

\footnotetext{
${ }^{81}$ L.A. Seneca, Epist. $44,3$.

${ }^{82}$ Cf. L.A. Seneca, Epist. 31,11.

${ }^{83}$ L.A. Seneca, Epist. 95,52s (com citação de Terencio, Heautontim. 77).

${ }^{84}$ Veja respectivamente: Epíteto, Diatr. 2,5,26; 2,10,3-5 («Tu és cidadão do mundo [politēs tôu kósmou] ... O todo é mais importante que a parte e a cidade mais que o cidadão »); e Marco Aurelio, Ric. 7,13 (onde se convida o homem a cnsiderar-se "membro" [mélos] e não apenas «parte» [méros] do todo/sýstēma dos seres racionais).
} 
rença a respeito das diferenças" é aquilo que toca profundamente qualquer autor contemporâneo não-crente ${ }^{85}$.

\section{Conceitos de proveniências diversas}

Paulo demonstra conhecer algumas concepções de caráter tipicamente helênico, expressas não somente em alguns vocábulos (cf. acima: 1) ou em conceitos filosófico-estoicos (cf. acima 4), mas em sintagmas construídos de forma diversa e de também expressões que denotam o modo de exprimir propriamente grego. Enumeraremos cinco:

5.1. O mais interessante diz respeito ao sentido da morte de Jesus em quanto "mortolentregue em favor de (para)" apéthanen/parédōken hypèr... ${ }^{86}$, em que a destinação da morte mesma em Paulo é especificada ou em sentido impessoal ("pelos pecados": formulação tradicional) ${ }^{87}$ ou mais freqüentemente no sentido pessoal ("para nós, para todos, para os ímpios, para o irmão) ${ }^{88}$. Ora "esta fórmula não tem correspondente no Antigo Testamento e na esfera das línguas semitas, mas é, ao contrário, freqüente nos textos gregos ${ }^{89}$. De fato, na Bíblia a eventual destinação da morte é determinada com outras preposições (TM $l l^{e},{ }^{c} a l$, min; LXX "peri" e "dia": seja nos textos sacrificais do Levítico, seja na carne do servo de YHWH em Is 53), quase sempre em sentido impessoal e não pessoal. $\mathrm{O}$ helenismo atesta, de outra parte, abundantemente o tema do enfrentamento da morte e da sua conclusão em favor de outros e expressa este ato com a preposição "para", hypér (inclusive com o verbo composto hyper-apothnéskein), e a sua destinação pode ser diversamente especificada: "pela cidade, pelos amigos, pela lei, pela liberdade, por todos os gregos, pela verdade, pelo país ${ }^{90}$. Valem para todos os dois textos: um de Eurípedes sobre o sacrifício de Efigênia ("Dou com prazer o meu corpo para ser sacrificado pela minha pátria e por toda a Hélade") ${ }^{91}$ e um de Epíteto sobre a amizade (“... colocar-se em perigo pelo amigo e, se necessário for, morrer por ele" $)^{92}$.

${ }^{85}$ Cf. A. Badiou, San Paolo. La fondazione dell'universalismo, Cronopio, Napoli 1999, 153.

${ }^{86}$ Cf. A precisão de M. Hengel, Crocifissione ed espiazione, Paideia, Brescia 1988, 181-182.

${ }^{87}$ Cf. 1Cor 15,3; Gal 1,4.

${ }^{88}$ Cf. Rm 5,6.8; 14,9; 1Cor 1,13; 8,11; 2 Cor 5,14.15.21; Gal 2,21; 3,13; 1Tes 5,10.

${ }^{89}$ M. Hengel, Crocifissione ed espiazione, 196-197.

${ }^{90} \mathrm{Cf}$. a ampla documentação oferecida por M. Hengel, Crocifissione ed espiazione, 139-165.

${ }^{91}$ Eurípides, Ifig. in Aul. 1553-1555: toumòn dè sôma tês emês pátras / kaì tês hapásēs Helládos gaías hýper / thŷsai dídōm' hekoûsa.

${ }^{92}$ Epitteto, Diatr. 2,7,3: kindyneûsai hypèr tổ fillou, àn dè kaì apothaneîn hypèr autoû kathē$k \bar{e}_{i}$. 
5.2. Em Rm 2,14-15, Paulo afirma que os Gentios "mesmo não tendo lei são lei para si mesmo: manifestando assim que a obra da lei está escrita em seus corações". Com estas palavras, o Apóstolo faz uma clara referência ao tema do nómos ágrafos, que é uma tradição na helenidade antiga. Isto pode ser testemunhado num arco de tempo que parte de Heráclito (com o conceito análogo de "harmonia invisível, melhor que aquela visível") ${ }^{93}$, e de Sófocles ("leis não escritas e imutáveis dos deuses", ágrapta kasfalê theôn nómima) ${ }^{94}$ e chega, pelo menos, até Dión de Prusa (que contrapõe a lei positiva dos estados à "lei da natureza", ho tês fýseōs nómos) ${ }^{95}$. Mesmo não sendo um tema exclusivo do estoicismo, mas foi a filosofia do Pórtico que o desenvolveu ${ }^{96}$, falando em termos de "lei comum" (koinós nómos) como se pode ver, por exemplo, no hino a Zeus de Cleonte ${ }^{97} \mathrm{e}$ em Epíteto ${ }^{98}$, para não dizer em Cícero ${ }^{99}$. No fronte judaico um papel muito importante, até mesmo sobre o plano lingüístico, foi desempenhado por Fílon de Alexandria ${ }^{100}$.

${ }^{93}$ Fr. 54 D-K. Vedi M.Gigante, Nomos basileús, Bibliopolis, Napoli ${ }^{2} 1993,50-55$.

${ }^{94}$ Sófocles, Antig. 454s.

${ }^{95}$ Diógenes Crisóstomo, Orat. 80,5-6; o mesmo Diõgenes distingue esplicitamente entre lei ágrafos e éggrafos (in Orat. 76,1.3; veja, contudo, Dionísio de Alicarnaso, Ant.rom. 2,74,1).

${ }^{96}$ Cf. H. Koester, «Nomos physeos. The Concept of Natural Law in Greek Thought», in J. Neusner, ed., Religions in Antiquity, Leiden 1968, 521-541; Ph. Mitsis, «Natural Law and Natural Right in Post-Aristotelian Philosophy: The Stoics and Their Critics», in ANRW II,36.7, 4812-4850.

${ }^{97}$ Cf. já o v.2 («Zeus, princípio da natureza, que todas as coisas com a lei governe») e mais, os vv. 12.20.24.38. Veja J.C. Thom, Cleanthes' Hymn to Zeus. Text, Translation, and Commentary, STAC 33, Mohr, Tübingen 2005, 49-52.

${ }^{98}$ A propósito do princípio segundo o qual aquilo que é melhor deve prevalecer sobre o que é pior, ele fala de modo análogo da «lei da natureza e de deus» (Diatr. 1,29,19: nómos tês fýseōs kaì toû theoû; em 3,17,6 o mesmo princípio vem definido «lei natural», nómos fysikós). ${ }_{99}$ Cf. De rep. 3,22,33: «A verdadeira lei é a reta razão em conformidade com a natureza (est quidem vera lex recta ratio naturae congruens), universalmente presente, estável e eterna (diffusa in omnes, constans, sempiterna), que chama ao dever com os seus comandos e desvia do mal com suas interdições ... Podemos desatarnos dessa lei por obra do senado ou do povo, não se aproxima um outro a nós que no-la explica e interpreta, não é uma lei para Roma e outra para Atenas, ou uma agora e outra para o futuro, mas uma só, eterna e imutável lei será válida para todos os povos e todos os tempos, e um será o mestre e guia de todos, Deus, ele que é autor dessa lei, promulgador e aplicador». Veja também De fin. 1,18-19: «A lei é a mais alta razão inserida na natureza [lex est ratio summa insita in natura], que ordena as coisas a serem feitas e proibe as contrárias, ... é, na verdade, a força da natureza [est enim naturae vis])».

${ }^{100} \mathrm{O}$ Alexandrino emprega os sintagmas lógos fýseōs («razão da natureza»: De Jos. 29), thesmoì tês fýseōs («ordenações da natureza»: ib. 30), orthòs lógos tês fýseōs («reta razão da natureza»: $i b .31)$. 
5.3. Em Rm 7,19, servindo-se de um "eu" retoricamente configurável como fictiolenallage personae, Paulo escreve: "Não faço o bem que quero, mas o mal que não quero" 101 . Neste cenário se poderia desenvolver a discussão sobre a akrasía ou "intemperança", própria de quem não sabe dominarse a si mesmo, à qual Aristóteles dedica todo o livro 7 da sua Ética a Nicômaco (cf. 7,1,145b: O incontinente, por causa da paixão, realiza ações mesmo sabendo que elas são más"). Mas o verdadeiro topos ao qual o texto paulino pode reduzir começa com o texto clássico de uma tragédia do século $\mathrm{V}$ a.C., A Medeia de Eurípedes, onde a heroína estrangeira, já em Corinto é traída pelo marido Jasão, faz a si mesmo violência para assassinar os dois filhos deles e exclama: "Estou vencida dos males (mikômai kakoîs), e entendo (manthánō) que vou fazer, mas a ira é mais forte que a minha vontade (thymòs dè kreíssōn tôn emôn bouleumátōn), esta que a causa dos piores males entre os mortais" ${ }^{\prime 102}$. Também Platão afirma repetidamente que os homens, mesmo conhecendo o bem, todavia praticam o mal ${ }^{103}$, e dá como razão que o bem não está a altura de vencer o mal ${ }^{104}$, de tal forma que "a alma sob o domínio de uma verdadeira tirania não fará de modo algum o que quer (hēkista poiēsei hà àn boulēthe $\hat{e}_{i}$ ), mas sempre arrastada com violência

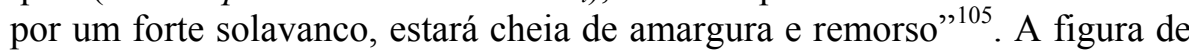
Medeia se torna pois um arquétipo especialmente na literatura e no estoicismo. Na literatura, deve-se citar Ovídio, mesmo que ele transfira o drama de Medeia ao seu momento inicial, quando ela ainda na Colquide não sabe resistir à fama do amor pelo estrangeiro Jasão: "Depois de ter lutado por longo tempo, vendo que com a razão não poderia vencer aquela louca paixão (postquam ratione furorem vincere non poterat), disse, em vão, Medeia, procura resistir, deve ser um qualquer deus que está se opondo... Minha desgraça, um impulso jamais experimentado antes me arrasta (sed trahit invitam nova vis) e a agitação interna me aconselha uma coisa e a mente uma outra. Veja as coisas melhores e as aprovo, mas sigo as piores (vídeo meliora pro-

\footnotetext{
${ }^{101}$ Cf. R. Penna, Lettera ai Romani - I. 1-5, SOC 6/I, EDB, Bologna 2004, 109-110.

${ }^{102}$ Med. 1077-1080. O mesmo Eurípides, em outra tragédia e em termos mais moralistas, confessa pela boca de Fedron: «Já outras vezes, nas longas noites, refletia sobre como se corrompe a vida dos homens. E me parece que esses fazem as coisas piores não por predisposição natural (ou katà gnōmēs fýsin), visto que muitos são sãos de mente, mas para mim, as coisas são assim: nós aprendemos e conhecemos o bem (tà chrēst'epistámetha kaì ginōskomen), mas não nos empenhamos em praticá-lo (ouk ekponoûmen) ou por pregriça ou porque se antepõem ao bem outros prazeres» (Ippol. 375-382).

${ }^{103}$ Cf. Platão, Protag. 352d.355a-c.

${ }^{104}$ Cf. ib. 355c-d.

${ }^{105}$ Platão, Republ. 577e.
} 
boque, deteriora sequor) ${ }^{106}$. Também Sêneca em uma de suas tragédias repete esta mesma fórmula, mesmo que transponha o drama para o amor incestuoso entre Fedra e seus enteado Hipólito: "Eu sei que o quanto foi dito é verdadeiro, mas uma louca paixão me constringe a seguir coisas piores (sed furor cogit sequi peio$r a)$. Mesmo que o saiba, a minha alma vai na direção do precipício e em vão busca bons conselhos (...). O que pode fazer a razão? Vence e reina a louca paixão, e um deus potente subjuga toda a mente (...). Chamo como testemunhas todos vós, ó Celestes, que eu não quero aquilo que quero (hoc quod volo me nolle) ${ }^{107}$.

No estoicismo da época imperial é encontrada a mesma temática, sobretudo em Epíteto. Nele, volta à tona o intelectualismo ético de Sócrates aplicado exatamente à Medeia: "Ela considerou mais vantagem render-se à ira e vingar-se do marido do que salvar os filhos... Claramente lhe é mostrado que ela se enganou (exēpátētai) e não o fará (kaì ou poiēsei) ${ }^{108}$; "Cada era de fato implica em uma contradição (pân hamártēma máchēn periéchei). Porque quem peca não quer pecar, mas fazer aquilo que correto, é claro que não faz aquilo que quer (ho mèn thélei ou poiề)... É então muito hábil aquele quem pode colocar diante de qualquer pessoa a contradição que a induz ao erro e, assim, provar-lhe claramente que não faz aquilo que quer, mas aquilo que não quer (ho thélei ou poieî kaì ho mé thélei poiề). Se se consegue mostrar isto a um homem, ele voltará atrás por si mesmo" 109 .

5.4. Uma difusa presença de pressuposições helênicas encontram-se no texto de 2 Cor $4,7-5,10$, no que se refere à concepção antropológica ${ }^{110}$. Deixando de lado a imagem do "vaso" (cf. 4,7: "Temos este tesouro em vasos de barro"), que pertence à Bíblia grega e pressupõe a idéia hebraica de Deus como oleiro ${ }^{111}$, Pau-

106 Ovídio, Metam. 7,10-11.19-21. Veja também Diodoro Sículo 1,71,3: «Frequentemente alguns, mesmo sabendo que estão por errar, todavia, cometem atos deploráveis, assoberbados do amor ou do ódio ou de alguma outra paixão».

${ }^{107}$ Sêneca, Fedron 177-185. 604s.

${ }^{108}$ Epíteto, Diatr. 1,28,7-8.

${ }^{109} \mathrm{Ib}$., 2,26,1-5. Um eco ulterior do caso de Medea se encontra em um escirto menor de Galeno, que fala de duas instâncias (dýo archai) no homem: uma logikē com a qual se conhecem as coisas e uma álogos que conduz às paixões irracionais («Exatamente essa produziu a violência [ebiásato] a Medea»: Plac. Hipp. et Plat. 408s).

${ }^{110}$ Cf. R. Penna, «Sofferenze apostoliche, antropologia ed escatologia in 2Cor 4,7-5,10», in Id., L'Apostolo Paolo. Studi di esegesi e teologia, San Paolo, Cinisello Balsamo 1991, 269298, especialmente 281-288; D.E. Aune, «Anthropological Duality in the Eschatology of 2 Corinthians 4:16-5:10», in T. Engberg-Pedersen, Paul Beyond the Judaism/Hellenism Divide, 215-239; e a exegese de A.Pitta, La seconda lettera ai Corinzi, Borla, Roma 2006, 211-251.

${ }^{111}$ Cf. todavia Cícero: «O corpo é como um vaso ou um contenedor do ânimo, nam corpus quidem vas est aut aliquod animi receptaculum» (Tusc. 1,22,52); além de: Lucrezio, Rer.nat. 3,440 e 555 . 
lo recorre a quatro imagens que têm clara ascendência grega. A primeira refere-se à distinção entre "o nosso homem exterior" (ho éxō hēmôn ántrōpos) e "aquele interior" (ho ésō hēmôn) $(2$ Cor 4,16$)$. Na base destes textos, pode-se observar uma perspectiva platônica ${ }^{112}$ que nos reenvia particularmente a Rep. 9,589 a-b ("o homem interior deve ter o máximo domínio sobre o ser humano", tôu anthrōpou ho entòs ánthrōpos éstai egkratéstatos), mas atestada em várias outras fontes ${ }^{113}$. A segunda consiste na imagem da "casaloikía" (2Cor 5,1-2a), na qual se pode facilmente encontrar a idéia platônica da morte como metoikessis, "troca de casa, mudança" (cf. Apol. 40c), assim também Filón de Alexandria, considera precisamente o corpo como oikía da alma ${ }^{114}$. A esta imagem pertence também aquela correlata da "tenda\skênos" (2Cor 5,1: oikía toû skēnous), da mesma forma muito bem atestada na helenidade pagã e também nos textos bíblicos ${ }^{115}$. Uma terceira imagem é aquela do exílio (cf. 2Cor 5,6.8.9). Já Sócrates falava de sua própria morte como "emigração" (apodēmía: Platão, Fed. 67), o mesmo conceito, além de ser comum em Platão (cf. De facie 943C), é encontrado sobretudo em Filón de Alexandria ${ }^{116}$. Uma última imagem antropológica usada por Paulo é aquela do contraste entre "vestido\nudez" (2Cor 5,2b-4). Já Empédocles falava da carne como "revestimento" (cf. 126 D-K), mas a idéia emerge em toda sua evidência em Platão (cf. Gorg. c-d sobre o juízo divino: ora os vivos estão "vestidos\ampechómenoi, mas depois estarão "nus\gymnoi) e será encontrada em Sêneca (cf. Epist. 92,13; 102,25). Pra um parecer sobre estes vários débitos paulinos em relação à helenidade será necessário reconhecer que estes são mais de linguagem do que de substância. Duas diferenças necessitam ser assinaladas: de uma parte, Paulo neste discurso antropológico não emprega jamais o binômio antitético sôma-psychē, evitando assim o típico dualismo platônico; de outra parte, em conseqüência disso, ele não despreza jamais o corpo, tanto é que o conceito de imortalida-

\footnotetext{
${ }^{112}$ Cf. T.K. Heckel, Der Innere Mensch. Die paulinische Verarbeitung eines platonischen Motivs, WUNT 2.53, Mohr, Tübingen 1993.

${ }^{113}$ Cf. Fílon de Alexandria, Det.pot.ins. 22s; Agr. 8.108; ecc.; Epíteto, Diatr. 2,7,3; 2,8,14; 3,3,13; além de: Corpus Hermeticum 1,15; Plotino, Enn. 3,2,15.

${ }^{114}$ Cf. Det.pot.ins.33; Praem. 120; Omn.prob.lib. 111; in Virt. 77 a morte é chamada apoikía. Veja-se também a idéia contrária, segundo a qual o corpo não é uma verdadeira casa, mas uma aliena domus (Cícero, Tusc. 1,22,51; e Senect. 23,84; Sêneca, Epist. 65,21) pois a verdadeira casa é o céu, depois da morte (cf. Cícero, Tusc. 1,22,51; Divin. 1,25,53).

${ }^{115}$ Cf. W. Michaelis, skênos, in GLNT XII, 486-487.

${ }^{116}$ Cf. Rer.div.her. 82: «A vida no corpo, toda inteira, é um exílio»; cf. também ib. 276; Somn. 1,180-181; Conf. 76-82.
} 
delathanasía é por ele paradoxalmente empregado especifica e propriamente a propósito do corpo (cf. 1Cor 15,53.54) ${ }^{117}$.

5.5. Um eco de um background grego pode ser ainda observado na afirmação de Fl 2,6-7 na passagem em que, na celebração hínica de Jesus Cristo, se fala de uma mudança de morfê daquela de Deus para aquela de um escravo $^{118}$. A afirmação pode ser compreendida melhor, tendo presente um assunto fundamental na filosofia grega, com o qual o nosso texto está em antítese. Este princípio encontra-se claramente expresso em uma página celebra da Republica de Platão, onde o filósofo polemiza diretamente contra os mitos e mitógrafos, que descrevem as várias metamorfoses dos deuses desonrados:

"Crês tu que os deuses sejam um charlatão capaz de aparecer, ao seu bel prazer, em diversos aspectos (en állais ideais), mudando sua aparência (alláttonta tò hautồ eîdos) em muitas formas (eis pollàs morfás)? Ou mesmo crês tu que seja um único (simples) e não saia absolutamente jamais do seu aspecto? A divindade e aquilo que diz respeito a ela gozam em tudo e por tudo da condição melhor... Em conseqüência disso deus estará sempre menos sujeito a assumir muitas semelhanças (pollàs morfás)... Se deve mudar, muda a si mesmo naquilo que é melhor e lindo... O que te parece? Uma pessoa qualquer não se importa se um deus ou um homem possa fazer-se pior por sua própria vontade? É impossível! Por isso é também impossível que um deus queira mudar a si mesmo (hautòn alloioûn); ao contrário, tendo a mais alto grau de beleza e de virtude, cada um permanece sempre absolutamente na própria forma (ménei aeì aplôs en tê $\hat{e}_{i}$ hautôे morfế $\left.\hat{e}_{i}\right)$ " (Rep. 380d381c).

Platão prossegue imediatamente depois desaprovando os contos dos poetas mitógrafos, especialmente de Homero e Esquilo, e recomenda às mães de não deixarem se influenciar na educação das crianças (cf. Rep. 381c-383c) ${ }^{119}$. Natu-

\footnotetext{
${ }^{117}$ Por isso a exortação que se lê em Rm 8,13 («Se com o Espírito sepultais as ações do corpo, vivereis») estando no contexto (no qual se contrapõe o Espírito à carne) significa simplesmente renunciar a uma autônoma afirmação de si; é mister preciar que não diz "mortificar" o corpo, mas as suas ações praticadas sob a influência da carne (cf. R.H. Gundry, "Sôma» in Biblical Theology, with Emphasis on Pauline Soteriology, SNTS MS 29, University Press, Cambridge 1976, 39).

${ }^{118}$ Cf. R. Penna, «Da forma de Deus à forma de escravo: duas categorias culturais no fundamento de Fl 2,6-7», em S. Grasso - E. Manicardi, a cargo, "Generati da una parola di verità» (Gc 1,18). Scritti in onore di Rinaldo Fabris nel suo $70^{\circ}$ compleanno, EDB, Bologna 2006, 279-287.

${ }^{119}$ Cf. 382d: «Em um deus não pode haver um poeta mentiroso». Nessa direção andava, já substancialmente, a crítica de Shenófanes de Colófanes, Framm. 11.12.15.16 D-K.
} 
ralmente, esta idéia da divindade coincide com o quanto pensa Platão e escreve em outro lugar sobre a sua absoluta imutabilidade. No Timeu, de fato, a propósito das expressões temporais do verbo "ser", ele escreve: "O Era e o Será são formas gerais de tempo, que nós inconcebivelmente referimos de modo errado como sendo eterno. Pois, nos dizemos que este Era e que É e que Será, mas somente o É lhe convém verdadeiramente, enquanto o Era e o Será devem ser ditos apenas para as coisas geradas no tempo" (Timeu, 37e-38a). Nesta linha, pode ser vista também a doutrina aristotélica da divindade como motor "imóvel, impassível e inalterável", akinēton, apathēs, analloiōton (cf. Metafisica $\Lambda$ [XII], 6-7,1071b-1073a).

Em oposição a isso, Homero faz com que Odisseu diga a Atenas: "É difícil, ó deusa, reconhecer-te quanto tu te encontras com um mortal, mesmo se é muito sábio: tu de fato te fazes igual a quem quer que seja! (Odisséia 13,312313). Do mesmo modo, Eurípedes nas Bacantes coloca estas palavras na boca de Dionísio: "Mudei a minha forma daquela de um deus para uma humanalmortal (morfên d'ameípsas ek theoû brotesían) ... Tenho um aspecto mortal após a mudança (eîdos thnētòn alláxas échō), e mudei a minha forma (morfên t'emēn metébalon) naquela da natureza de um homem (eis andròs fúsin)" (vv.4 e 53-54) ${ }^{120}$. Ainda desta forma, Ovídio inicia as suas Metamorfoses (que sem dúvida referem-se a deus, se bem que não somente de deuses) com este verso programático: In nova fert animus mutatas dicere formalcorpora ("a inspiração poética me estimula a narrar de formas mudadas em corpos novos").

Ora, a afirmação de Fl 2,6-7 coloca-se em rota de colisão com esta, assim chamada, concepção filosófica da divindade, enquanto, paradoxalmente, encontra-se na mesma linha daquela mitológica, que a filosofia combatia. $\mathrm{O}$ fato que fale até mesmo de uma kénosis daquele que existia "em forma de deus" não há algum confronto lingüístico possível. O gnosticismo sucessivo falará da divindade como pertencente à esfera da "plenitude $\backslash$ plèrōma e deste mundo inferior

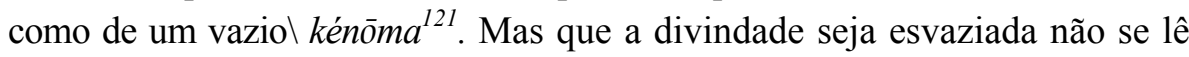
em nenhuma parte. Sem dúvida, a afirmação de Fl 2,7 (heautòn ekénōsen) deve

\footnotetext{
${ }^{120}$ Ainda mais eloquente é o caso de Apolo, narrado pelo mesmo poeta, na Alcesti final de seu incipit: Aqui deus recorda de ter feito o bovaro para o serviço de Admeto, rei di Fere in Tessaglia, obrigado pelo Pai, Zeus, que o tinha expulso do céu. O mito narra que Zeus expulsou Apolo do céu por um ano como punição por aver matado os Ciclopes; esse crime significa um ato de repúdio contra Zeus, que o tinha incumbido de construir um raio com o qual fulminou o médico Asclepio (filho do mesmo Apolo e da senhora mortal Coronides) visto que essa tinha ressuscitado dos mortos, uma atitude que Zeus não podia tolerar, temendo que a mesma provocasse uma convulsão na ordem do mundo (cf. P. Grimal, Dizionario di mitologia greca, Paideia, Brescia 1987, 77-78 com citações das fontes).

${ }^{121}$ Cf. K. Rudolph, La gnosi. Natura e storia di una religione tardoantica, BCR 63, Paideia, Brescia 2000, 117-141. No Corpus Hermeticum o tratado 'Poimandres' especula sobre Nô̂s divino que produz o homem, a quem doa a própria morfē (cf. I,12-15).
} 
ser compreendida como uma metáfora, que é bem compreensível enquanto tal seja pelo particular contexto celebrativo em que está inserida, seja pelo transfundo de um uso imaginativo do verbo kenoûn, como se encontra no grego da LXX (cf. por exemplo, em Rt 1,21 onde Noemi exclama: "Parti plena e o Senhor me fez voltar vazia", isto é, humilhada). Em todo caso, isto não garante a concretude extrema da afirmação e o "escândalo" que tal expressão devia suscitar nos leitores e ouvintes mais refinados. Talvez seja para atenuar uma impressão similar que Orígenes, retomando a categoria platônica da imutabilidade, justifica a mudança ocorrida em Jesus: "Por seu amor aos homens "esvaziou-se a si mesmo"... Nenhuma mudança verdadeiramente aconteceu nele saindo da excelência até a extrema baixeza humana: como é possível que seja mesmo extrema baixeza a bondade e o amor pelos homens? (Contra Celsum 4,15).

Permanece ainda o fato da afinidade entre o nosso texto com a mitologia. Isto não deve ser causa de uma grande surpresa. Ao contrário, a constatação é interessante e fecunda. A fé cristã, na verdade, não tem para proclamar uma verdade abstrata sobre a natureza da Divindade ou do Ser em si mesmo, mas sim tem essencialmente alguma coisa para contar. A sua profissão de fé é mais próxima da narrativa que da filosofia. Vale a pena recordar, enfim, que o termo mythos em grego significa fundamentalmente "narrativa ${ }^{122}$. É bem verdade que a narrativa do evangelho cristão não diz respeito à sua vez a uma qualquer mera verdade sapiencial, universal e desencarnada, mas tudo ao contrário, concentrase sobre uma personagem histórico enquanto protagonista de eventos únicos no seu gênero, que devem ser narrados (contados), mesmo que também devam ser interpretados. Falando isto com uma linguagem joanina, a história de Jesus é aquela de uma "encarnação". Analogamente, a passagem Fl 2,6-7 exprime uma sua própria hermenêutica do Kerigma narrativo que lhe está acima. Esta, ao início se interessa pelo estágio pré-histórico de Jesus Cristo, ou melhor, da sua passagem de uma condição de existência à outra, de uma morfē para outra. A pessoa e a história de Jesus são assim interpretadas em sentido cristológico, afirmando que ele se fez obediente "até à morte e uma morte de cruz", isto quer dizer que, estava inicialmente em uma condição totalmente outra ${ }^{123}$, divina, à qual, inesperadamente renunciou para assumir uma condição de escravo. Em tudo isso, a categoria da mitologia funciona como um meio expressivo, o

\footnotetext{
${ }^{122}$ Cf. o final estereotipado das fábulas de Esopo: ho mýthos delô̂, «a narrativa (não apenas a fábula) ensina». Em geral, cf. por exemplo J.-P. Vernant, Mito e pensiero presso $i$ Greci. Studi di psicolologia storica, Einaudi, Torino 2001. Para uma boa centralização da discussão da matéria, cf. G. Betori, «Mito», in P. Rossano, G. Ravasi, A. Girlanda, a cargo, Nuovo dizionario di teologia biblica, San Paolo, Cinisello Balsamo 1988, 993-1012.

${ }^{123}$ Sobre a referência no v.6 tra en morfe $\hat{e}_{i}$ theou e tò eînai isa theô $\hat{o}_{i}$, cf. D. Burk, «On the Articular Infinitive in Philippians 2:6: A Grammatical Note with Christological Implications», TyndBull 55 (2004) 253-274.
} 
que evidencia uma certa analogia fundamentada sobre uma comparação cultural, mas que em termos de conteúdo divergem totalmente.

Além disso, é necessário ainda precisar que os contos da mitologia helênica não tiveram um real confronto com o âmbito semítico ${ }^{124}$. Nela, como se sabe, comporta um panteão muito numeroso, contracenado por um difuso e acentuado antropomorfismo. Mas a presença dos deuses entre os seres humanos acontece, sobretudo, mediante específicas e solenes teofânias, sem contar o fato que se acreditasse na divindade de alguns homens (de fato somente os reis) e, eventualmente, de algum animal. Isto não implica verdadeiras e próprias metamorfoses temporâneas das várias divindades em formas humanas, das quais, pois, não existem narrativas que se possam comparar àquelas da mitologia grega ${ }^{125}$. Há uma exceção, que é aquela narrada no mito babilônico de Era (deus dos infernos e da destruição); que ecoando novamente alguns momentos trágicos vividos pela Babilônia na segunda metade do II milênio a.C., quando foi invadida pelos suteus, dirige-se ao deus assim: $\mathrm{Tu}$ mudastes a tua divindade para fazer-te igual ao homem, tu revestistes as tuas armas e entrastes na cidade... Tu tomastes um aspecto de leão e entrastes no palácio" (IV, 4 e 21) $)^{126}$. Mas é claro que se trata de pura metáfora para dizer que os invasores eram emissários e representantes de deus.

\section{Analogias religiosas com os cultos mistéricos?}

$\mathrm{O}$ ponto de interrogação refere-se à possibilidade de individuar em Paulo eventuais consonânciasldependências no âmbito da linguagem não somente filosófico, mas propriamente religioso. Ao mesmo tempo, essa interrogação quer ainda homenagear muitas perplexidades que os estudiosos arriscam neste campo do comparativismo. Para citar de imediato um dos grandes cultivadores desta matéria: Walter Burkert; nos mistérios pagãos "não existe nada que explicitamente soe como as passagens no Novo Testamento, especialmente, em São Paulo e no Evangelho de João, que faça referimento ao morrer com Cristo e o renascimento espiritual. Não existe ainda

\footnotetext{
${ }^{124}$ Cf. por exemplo S. Moscati, Le antiche civiltà semitiche, Feltrinelli, Milano 1961, 43-45; P. Garelli-V. Nikiprowetzky, Le Proche-Orient Asiatique - II. Les empires mésopotamiens, Israël, PUF, Paris 1974, 169-172; e D. Modenini, Mitologia delle origini, Spaziotre, Roma 2000.

${ }^{125}$ Outra coisa é a crença em seres angelicais (ou demoníacos) intermédios, que aparecem sim aos homens, mas que não condividem a divindade no sentido estrito.

${ }^{126}$ Cf. R. Labat, Les religions du Proche-Orient asiatique. Textes babyloniens, ougaritiques, hittites, Fayard, Paris 1970, 129-130.
} 
nenhuma prova de caráter histórico-filosófico que tais passagens sejam derivadas dos mistérios pagãos" $" 127$.

Todavia, e isto deve ser dito em linha de princípio, não é necessário deixar-se apressadamente cegar-se pelas preocupações apologéticas ${ }^{128}$; o importante é considerar com objetiva honestidade os textos e os temas relativos a este argumento. Certamente, não se trata apenas do binômio morrer-renascer|ressurgir, sobre o qual Burkert pode ter razão ${ }^{129}$. Por exemplo, quando Paulo escreve que "seja no céu, seja na terra (...) existem muitos deuses e senhores" (1Cor 8,5$)$, não se pode não pensar que ele tivesse presente, além do culto citado um pouco acima a propósito de Tarso, a multiplicidade dos outros cultos helênicos do tempo. Obviamente, ele conhecia melhor do que nós as expressões da religiosidade grego-romana, e se em Rm 2,22 condena os judeus por "rapinar os templos" (hierosyleîn) é porque demonstra, pelo menos, um respeito formal em relação aos lugares do culto pagão ${ }^{130}$. Por fim, é importante obser-

${ }^{127}$ W. Burkert, Antichi culti misterici, Laterza, Roma-Bari 1989, 134. Veja também M.M. Wedderburn, Baptism and Resurrection. Studies in Pauline Theology against Its GraecoRoman Background (WUNT 44), Tübingen 1987; M.W. Meyer, "Mystery Religions", in: $A B D$ IV, 941-945; D.E. Aune, "Religioni Greco-Romane", 1293-1310 (com bibliografia). Contra essas conclusões muito purdentes, para não dizer negativas, não valem as afirmações maximalistas e preconceituosas de H. Maccoby, Paul and Hellenism, London-Philadelphia 1991, segundo ele, especialmente a idéia de uma salvação procurada por «um deus descido na terra e morto conv violência» (p. 183) afastaria, irremediavelmente, Paulo do judaísmo.

${ }^{128}$ Até mesmo um apologista como Justino não tinha escrúpolo de afirmar: «Quando nós dizemos que o Logos, que o primogênito de Deus, Jesus Cristo o nosso mestre, foi gerado sem relação, e que foi crucificado e mor e ressuscitado, e subiu ao céu, não apresentamos alguma novidade no que concerne aqueles que, junto a vós, são chamados filhos de Zeus» (I Apol. 21,1; ele, no entanto, está pronto a afirmar as excessões, como em 55,1 sobre a crucifixão).

${ }^{129}$ Cf. também E. Ferguson, Backgrounds of Early Christinity, Eerdmans, Grand Rapids MI $1987,{ }^{2} 1990$, especialmente $132-240$.

${ }^{130} \mathrm{O}$ caso projetado por Paolo, ainda que não se devesse verificar com frequencia, é, no entanto bem atestado no âmbito do judaísmo helenístico, enquanto os judus da diáspora, não obstante não partilhando da idolatria dos gentios, são, seguidamente solicitados a respeitar a religião dos pagãos, inclusive os deus es e os seus templos. Assim Fílon de Alexandria e Flávio Josefo fazem valer o texto de Ex 22,27, segundo a versão grega dos LXX, que se diferencia do hebraico («Não blasfemarás Deus»), afirma, curiosamente, o plural: «Não blasfemarás os deuses»! Fílon, mesmo constatando com desgosto que o mundo conhecido está cheio de ídolos de madeira e pedra, afirma: «Nós devemos abstarnos de insultá-los, a fim de que não suceda que os seguidores de Moisés assumam o hábito de tratar com leviandade o nome "deus", em geral, sendo esse um título digno do mais alto respeito e amor » (Mos. 2,205; cf. 2,203-205; Spec.leg. 1,53.). Josefo escreve explicitamente: «Que ninguém blasfeme os deuses venerados em outras cidades, nem roube nos tempos dos outros (mêdè sylân hierà xeniká), nem tome um tesouro que tenha sido dedicado ao nome de algum deus» (Ant. 4,207; cf. C.Ap. 2,237). Paulo, no entanto, de um lado reconhece o zelo anti-idolátrico dos judeus de Roma, mas de outro, constata e critica o fato de que isso tenha sido uma desvalorização e desrespeito à religiosidade de outros. 
var que o Apóstolo polemiza muito mais com a Lei Mosaica (à qual dedica ampla argumentação) ${ }^{131}$ que contra a religiosidade pagã (cf. Rm 1,18-23) ${ }^{132}$.

Existem dois aspectos da questão, sobre os quais gostaria de chamar atenção para tentar formular, quem sabe, uma hipótese sobre Paulo.

6.1. Tradição e novidade. Como sabemos, o cultos mistéricos na época helenística ${ }^{133}$ apareceram para satisfazer as necessidades de uma religiosidade pessoal. De fato, estes cultos implicam na superação do tradicional culto dos cidadãos prestado aos deuses olímpicos. Diferentemente, dos gloriosos e impassíveis deuses do Olimpo, os assim chamados "deuses do embate do dia a daí" dos mistérios ofereciam a garantia de uma maior proximidade às carências do homem e a certeza da intervenção deles para salvar, seja nesta vida (com a libertação das doenças e perigos), seja na vida futura (com a garantia da beatitude depois da morte). Estes cultos, de um modo ou de outro, rompiam o quadro do culto cívico, que o oráculo de Delfos, segundo Cícero, chamava de mos maiorum a ser seguido sempre.

A tipologia destes mistérios é diversificada, mas é interessante a classificação proposta por Burkert, que individua três tipos principais: o primeiro é aquele construído sobre a figura de um só vidente, profissional itinerante ou carismático (cf. Alexandre de Abonuteico); existe um outro que privilegia o clero pertencente a um determinado santuário onde se ministra aquele culto (por exemplo, o culto de Asclépio ou de Íside); por fim, temos o tipo impostado sobre o grupo dos devotos, o thíasos ou o koinón (em latim o collegi$u m$ ), onde prevalece a idéia de uma remissão em conjunto, entre iguais e por interesses comuns (típico é o culto de Dionísio). Todas as três tipologias são de qualquer modo representativas a respeito do quadro da tradição religiosa cívica. É verdade também, como bem documento um importante estudo de Goodman, nenhum destes cultos exerceram uma verdadeira atividade de proselitismo. Mas, onde esses cultos chegavam e eram praticados, colocavase em movimento uma espécie de alternativa em relação à religião cívica dos cidadãos. O caráter de desestabilização e, de algum modo, alternativo de alguns destes cultos aparece bem claro em pelo menos uns dois casos, em que se deu uma reação polêmica em relação a eles. Um destes casos tem haver com o culto de Dionísio com seus relativos Bacanais em Roma no

\footnotetext{
${ }^{131}$ Cf. por exemplo A. Pitta, Paolo, la Scrittura e la Legge, EDB, Bologna 2008, 131-160 («La lettera ai Galati e lo scacco della Legge»).

${ }^{132}$ Cf. R. Penna, Lettera ai Romani - I. 1-5, 181-182.

${ }^{133}$ Veja uma excelente exposição em R. Turcan, Les cultes orientaux dans le monde romain, Les belles lettres, Paris 1989; e mais breve em E. Ferguson, Backgrounds of Early Christianity, 197-240.
} 
início do século II a. C.; o cônsul Postúmio, que conduziu as pesquisas, dirigiu-se ao povo imediatamente antes do decreto de degredação (emanado pelo senado em 186 a.C.) dizendo que os ancestrais "estavam convencidos que nada se presta tanto para destruir o sentimento religioso que realizar os sacrifícios não segundo as normas tradicionais, mas com ritos estrangeiros (non pátrio sed externo ritu). $\mathrm{O}$ outro caso, ainda em Roma, refere-se à proibição do culto a Íside emanado por Tibério, antes que se afirmassem as simpatias isiádicas de Calígula: os sacerdotes deste culto foram crucificados, o tempo de Íside foi derrubado e a estatua da deusa foi jogada no Tibre.

A hipótese que com toda circunspeção se poderia formular a propósito de Paulo, sobre as bases destas constatações, é que Paulo tenha se comportado em relação a Israel analogamente aos iniciadores de um novo culto de dimensões mais acessíveis e mais universais do que a consolidada religião de Israel previsse ou permitisse. Quero dizer que os cultos mistéricos podem ter influenciado sobre Paulo, se não nos detalhes de seus componentes constitutivos, pelo menos na sua característica de alternativa ao tradicional fixismo do culto cívico oficial. Mas Cumont no seu clássico estudo sobre a religião oriental no império romano, interroga-se sobre vários possíveis motivos da sua propagação, observa sabiamente, entre outras coisas, que "o conservadorismo, enquanto todas as outras coisas estão submetidas a uma mudança contínua, traz sempre em si mesmo um germe de morte". A fé cristã, que segundo a hermenêutica paulina era entendida como anti-cultualística por sua interioridade e universalidade acessível pela sua simplicidade, pode ter desempenhado, talvez inconscientemente, em Paulo um papel de alternativa ao quadro religioso consolidado pela tradição. Esta é exatamente a reprovação que, segundo Lucas, o judeu-cristão Tiago faz ao apóstolo quando este chega a Jerusalém ao final da assim chamada terceira viagem missionária: "Escutei que vais ensinando a todos os judeus espalhados entre os gentios que abandonem Moisés, ensinando que não devem circuncidar mais os seus filhos e de não seguir mais as nossas tradições comuns" (At 21,21). Que o Apóstolo assim se comportasse na relação com os judeus é sem dúvida discutível, e os comentadores notam bem isto, mas que ele adotasse esta liberdade em relação aos gentios não pode se colocado em dúvida.

6.2. A comunhão com o deus cultual. O ponto de referência para esta parte do meu discurso é a figura de Dionísio como deus do vinho e do êxtase ligado ao estado de embriagues. Deixamos aqui de lado a mitologia das suas origens e em particular a história da sua "paixão". Aquilo que me interessa notar, em primeiro lugar, é o fenômeno de uma certa identificação entre o deus e o seu iniciado. De fato, bákchos, mesmo tendo uma etimologia incer- 
ta, não é apenas um epíteto do deus (cf. Sófocles, Édipo rei 211), mas tornase também uma qualificação própria de quem "é toma" pelo deus (cf. Heródoto 4,79,1-4). Platão reproduz como conhecido e difundido o dito, segundo o qual "muitos são aqueles que carregam o bastão enfeitado de Baco, mas poucos são bákchoi" (Fed. 69C), para dizer o que ocorre, sim, uma invasão do alto, mas que por isso os afortunados são assimilados pela divindade (tanto é que na outra vida "habitaremos com os deuses", em vez de habitar no lama".)

Em segundo lugar, acentuamos neste tipo de religião a típica importância do vinho, que chega a ser equiparado ao sangue. Se já na Bíblia o vinho é descrito imaginativamente como "sangue da uva" (LXX haîma stafylês: Gn 49,11; Sir 39,26). Em outra parte, na helenidade pagã a metáfora é empurrada para muito além chegando a designar até mesmo "o sangue de Baco" (haîma Bakchóu: assim o poeta ditirâmbico do séc. V-Via.C. Timóteu, fr.4). A mesma assimilação está implícita no verso de Eurípedes, onde afirma por metonímia que Dionísio "tornou-se um deu que se derrama em libação para os outros deuses" (Bac. 284). Sobre esta espécie de identificação, Cícero ironizará julgando não irracional consideram "deus" a sustância material da qual se pode si nutrir. Ainda, por fim, devemos constatar a presença do vinho como parte integrante do concreto desenvolvimento do culto dionisíaco, como ocorre nas várias festas dedicadas a ele.

Agora, se passamos ao Novo Testamento, encontramos a explícita declaração paulina segundo a qual a assunção do cálice de vinho na ceia eucarística constitui uma comunhão com o sangue de Cristo: "O cálice da bênção, que abençoamos, não é na verdade comunhão com o sangue de Cristo (ouchì koinōnía estìn tô̂ haímatos tô̂ Christoû)?» (1Cor 10,16a). Bem no centro da frase existe a indubitável afirmação de uma particularíssima "comunhão" com Cristo e com o seu sangue, que constitui o dado essencial do ato realizado. Ora, pelo fato de ser uma formulação do gênero exclusiva de Paulo e não se encontra em outro lugar no N.T., se põe, assim, inevitavelmente um problema: de onde a Apóstolo pôde ter derivado uma tal concepção? Certo é que temos de considerar natural que na base do texto paulino esteja sem sobra de dúvida a tradição proto-cristã sobre as palavras de Jesus sobre o cálice na última ceia (cf. 1Cor 11,23-26), onde, no entanto, não se fala de koinonía.

Neste ponto se poderia fazer uma digressão sobre a origem do vinho como ingrediente da celebração da Páscoa judaica. Como se sabe, a narração bíblica da ceia pascal contém somente referência ao anjo e ao ázimos, mas não se fala do vinho (cf. Ex 12). O problema se coloca, então, sobre a interrogação de quando o vinho fez o ingresso na celebração pascal. O celebra 
"papiro pascal" de Elefantina, datado do ano $5^{\circ}$. De Dario II (isto é, no 419418 a.C.), entre várias prescrições diz também para "não beber" durante os sete dias dos ázimos. O texto mais antigo que se pode citar sobre isso remonta aos fins do séc. II a.C. e está no Giub. 49,6 ("E todo Israel estava, de fato, comendo carne de páscoa e bebendo vinho, louvando, celebrando e bendizendo o Senhor": com referência a páscoa do Êxodo!). Ainda, Filón de Alexandria faz um aceno muito vago quando escreve que na ceia pascal os comensais são precedentemente purificados, "porque eles estão ali não como em outros banquetes para satisfazerem o ventre com vinho e comidas, mas para cumprir um costume ancestral com orações e hinos" (Spec. Leg. 2,148). Flávio Josefo não faz nenhuma espécie de alusão (cf. Ant. 2,311-313; 3,248251). Além disso, tanto o Targum sobre Ex 12 quanto antigo midraxe Mek.Ex. sobre o rito da pascal discorrem somente de comidas e jamais de bebidas. A prescrição ritual, própria e claramente, de beber vinho na festa da Páscoa é encontrada somente mais tarde no Midraxe (cf. ms.Pes. 10,1: "Na vigília de Páscoa, desde o momento em que se aproxima o tempo de oferecer o sacrifício vespertino, não é mais permitido comer até que se tenha anoitecido, e mesmo o mais pobre em Israel não deve comes até que não se tenha se colocado à mesa, assentado e devidamente apoiado; e não deve ter menos de quatro cálices de vinho, mesmo que fosse um daqueles que se alimenta com a tigela dos pobres"; mas mesmo aqui as três coisas consideradas principais do banquete pascal são o cordeiro.os ázimos e as ervas amargas (cf. ib.10,5), e não o vinho, propriamente, não obstante a sua relativa quantidade. Quanto ao significado do vinho, ele consiste seguramente no fato de que o vinho é sinal de festa, porque de um modo geral era bebido somente em circunstâncias toda especiais.

Mas isto ainda não é suficiente para responder de modo exaustivo à nossa pergunta, visto que de todo modo, Jesus não fala de koinônía. De fato, é necessário ulteriormente pesquisar a possível pré-compreensão que pode ter fornecido ao Apóstolo o módulo interpretativo da celebração eucarística e ter permitido a ele de conceber e, sobretudo, e de formular neste modo a realidade de uma comunhão 'vertical' (e não só 'horizontal' entre os comensais). Então, o discurso não se referee somente mais ao vinho, mas também ao pão (cf. 1Cor 10,16b: "O pão que partimos não é koinônía com o corpo de Cristo?") e até mesmo a totalidade de ceia. Esta é de fato definida como kryakòn deîpnon "ceia do Senhor" (1Cor 11,20), enquanto isto se trata de uma comida, que não é somente contraposta à comida de cada um (cf. 1Cor 11,21: tò ídion deîpnon), mas, sobretudo, é contracenado pelo Senhor mesmo, sejam pelo fato de ser preparado por ele ou em seu nome, seja pelo fato de ser dominado por sua presença. 
Então a resposta pode ser de dois tipos, de acordo com os dois diversos âmbitos culturais que podem estar presentes no transfundo do texto.

Em primeiro lugar, pode-se tentar uma referência ao transfundo vétero-testamentário. De fato, Paulo depois da citação apresentada acima continua assim: "Olhai o Israel terreno: aqueles que comeram as vítimas são participantes do altar (koinōnoì toû thysiastēriou)" (1Cor 10,18); e não pode ser senão uma alusão ao assim chamado "sacrifício de comunhão" (TM zebāh š lamîm; LXX thysía sōtêríou), descrito no livro do Levítico (cf.Lv 3; 7,11-36). Mas este propósito se deve observar duas coisas. Uma é que o tal sacrifício, segundo o texto bíblico, não implica nenhuma união mística com Deus, porque se trata somente de comer "diante do Senhor" (cf. Dt 27,7: TM lifnê YHWH; LXX enantion kyriou) e não "com" ele. A segunda é que estes sacrifícios mesmo que centrados necessariamente sobre sangue (cf. Lv 7,14), não somente o sangue não é e não pode ser bebido, mas também não tem absolutamente nada a haver com vinho, que destes sacrifícios é completamente excluído.

Em conseqüência de tudo isso, em segundo lugar, abre-se a perspectiva da possibilidade de ver um elemento de condicionamento cultural da concepção paulina propriamente originário do transfundo grego e, em particular, das celebrações de Dionísio. Teremos como ponto de referência somente o tema da recíproca identificação mediada pelo vinho. No entanto, é necessário admitir que dos textos referentes ao culto de Dionísio não aparece o específico vocabulário da koinōnía. Pode ser que Paulo tome este conceito da concepção dos cultos mistéricos em geral, nos quais ocorre com freqüência. A ciência religionista elaborou sobre esta matéria um certo vocabulário específico, entre os quais destacam-se os termos técnicos de "theophagia" e de "theoxenia", mas não existe um vocábulo que soe como "theoposia", que exprima diretamente a idéia de uma comunhão com a divindade através do ato de beber. Tudo isso deve nos alertar para a possibilidade de alargar os dados de comparação à nossa disposição (também porque nem Paulo nem outros nas origens do cristianismo falam nem mesmo uma só vez de uma manducação de deus!). No entanto, como já vimos anteriormente, o deus grego do vinho é celebrado não somente por meio de composições poéticas, mas também e, sobretudo, por meio de celebrações cultuais.

Assim, devemos honestamente constatar que o único paralelismo possível com o conceito paulino de comunhão com Cristo por meio do vinho, transformado em seu sangue, encontra-se na tradição grega sobre Dionísio, que pode ter funcionado como uma providencial praeparatio 
evangelica, mesmo devendo precisar que "o problema da gênese da noção de koinônía não deve ser confundido com aquele da originalidade teológica". Sobre este tipo de correlação, pode ser muito interessante recordar também um apócrifo judaico, seguramente retocado por mãos cristãs, que nos oferece uma original especulação sobre a árvore da vida e sobre o seu fruto. Trata-se de 3Bar (ou apocalipse grego de Baruch), datado nos dois primeiros séculos da era comum.

Segundo este livro, a árvore com a qual Adão e Eva pecaram era uma videira, e o diabo invejoso por meio dessa ("a sua videira") os enganou; por isso, Deus irado amaldiçoou a videira e o diabo (cf. 4,8). A Baruc, que pergunta como é possível que a videira seja agora de tão grande uso, o angelus interpres dá esta explicação: quando aconteceu o dilúvio, as águas chegaram até o paraíso e destruíram todas as plantas, mas Deus tirou de lá um broto da videira e o levou para fora. Tendo terminado o dilúvio, Noé descobriu a planta e não sabia o fazer com ela; quando o mesmo anjo the explicou todas as coisas, ele perguntou: "Se Adão por seu meio foi destruído, também eu encontrarei por meio dela a ira de Deus? $(4,13)$. E, então, implorou a Deus durante 40 dias para saber o que deveria mesmo fazer. Então, Deus the mandou o anjo Sarasael, que assim lhe falou: "Levanta-te, Noé, e planta o broto da videira, porque assim diz o Senhor: "A sua amargura se transformará em doçura, e a sua maldição tornar-se-á uma bênção, e o seu fruto se tornará o sangue de Deus (genēsetai haîma theôu), e como a raça humana foi condenada por seu meio, assim, por meio de Jesus Cristo Emanuel, como ele receberão o convite e o ingresso no Paraíso $(4,15)$.

Como se notará, a mão cristã é evidente, mesmo que intervenha sobre uma base seguramente judaica. Mas a coisa mais surpreendente é a designação do fruto da videira, isto é o vinho, como "sangue de Deus". A alusão à eucaristia, mesmo se não ulteriormente especificada, deve ser considerada fora de qualquer dúvida, mas em todo caso, a qualificação é totalmente original e, pelo que se sabe, não encontra nenhum outro paralelo, se não, caso seja assim, com a tradição grega a cerca da celebração do vinho em relação a Dionísio-Baco. De fato, a expressão é excessiva até mesmo para um cristão, que ao extremo fala de "sangue de Cristo", mas não "de Deus". Em todo caso, que o vinho é apresentado positivamente não por si mesmo, mas somente por uma dimensão que podemos definir como "sacramental". Isto é como dizer que o novo deus, do qual o vinho é agora o sangue, não pode mais ser identificado com Dionísio, mas com "Jesus Cristo Emanuel". 


\section{Conclusão}

De tudo isso que falamos, o resulta que a postura de A. Schweizer, referida logo no início, deve ser redimensionada. Seguramente, existem temáticas paulinas, absolutamente centrais no pensamento de Paulo, que não devem realmente nada ao helenismo: por exemplo, além das premissas judaicas do monoteísmo, do messianismo, e do recurso exclusivo às Escrituras de Israel, tudo aquilo que diz respeito à justificação pela fé sem as obras da Lei, a ressurreição de Jesus, e também, toda a temática relacionada à escatologia. De outro lado, tem também alguma coisa que Paulo não deve nem a Gregos e nem a Judeus, como por exemplo, a idéia da revelação do poder de Deus na fraqueza da cruz, que é escândalo para uns e loucura para outros (cf. 1Cor 1,18-25).

Mas não se deve considerar pouco relevante o fato de que o Apóstolo demonstra de todo modo sensível ao ambiente greco-romano, no qual prevalentemente vive e realiza a sua obra, servindo-se dialogicamente de algumas de suas categorias para se exprimir. Pode-se dizer que os ganchos com a helenidade se estabelecem, sobretudo, em nível de linguagem e que são realmente marginais no quadro do pensamento paulino. Resta o fato que por seu próprio testemunho, o Apóstolo, além de ser Judeu com os Judeus, ele se fez "com quem era fora da Lei como se fosse sem Lei" (1Cor 9,21), com isto, ela esta dizendo de ser de fato "Grego com os Gregos".

A história do pensamento cristão continuará nesta mesma linha de forma ainda mais mássica, como se verá a partir de São Justino (com o seu conceito de lógos spermatikós) até pelo menos a São Basílio (com o seu discurso aos jovens sobre a cultura grega). Certo é que, mesmo sem ceder a formas de sincretismo helenizante, e contrariamente ao que defendia Tertuliano, entre "Atenas e Jerusalém" existem mais coisas em comum de quanto se esteja preventivamente dispostos a pensar.

\section{Résumé}

La dynamique de la théologie pauline trouve plusieurs matis pour se fonder dans la culture grecque, particulièrement dans le stoïcisme, sans écarter une influence du romanticisme, surtout sous les aspects juridiques.

En son rencontre évangélisateur chez les peuples profondément hellénisés, Paul réalise de manière magistrale l'inculturation du Kéryg- 
me, en profitant plusieurs éléments de la culture helléniste, rendant plus prospères et efficaces les chemins de l'Évangile.

À ceux qui résistent d'accepter la présence d'éléments grecques dans la théologie et dans les écrits authentiques de Paul, la réponse est donnée, de manière très sérieuse et, méthodologiquement, très bien documentée, en cet article, par Romano Penna.

Romano Penna

Doutor em Ciências Bíblicas pelo Instituto Bíblico, Roma Docente Ordinário, desde 1983, do Novo Testamento na Pontifícia Universidade Lateranense, Roma 